January 2014

\title{
Mutual Funds, Fairness, and the Income Gap
}

Samuel D. Brunson

Loyola University Chicago, sbrunson@luc.edu

Follow this and additional works at: https://ecommons.luc.edu/social_justice

Part of the Law Commons

\section{Recommended Citation}

Brunson, Samuel D., "Mutual Funds, Fairness, and the Income Gap" (2014). Social Justice. 5.

https://ecommons.luc.edu/social_justice/5

This is brought to you for free and open access by the Centers at Loyola eCommons. It has been accepted for inclusion in Social Justice by an authorized administrator of Loyola eCommons. For more information, please contact ecommons@luc.edu. 


\section{Mutual Funds, Fairness, and the Income Gap Samuel D. Brunson*}

\section{ABSTRACT}

The rich, it turns out, are different from the rest of us. The wealthy, for example, can assemble a diversified portfolio of securities, or can invest through hedge and private equity funds. When the rest of us invest, we do so largely through mutual funds. Nearly half of American households own mutual funds, and mutual funds represented a significant portion of the financial assets held by U.S. households.

The tax rules governing mutual funds create an investment vehicle with significantly worse tax treatment than investments available to the wealthy. In particular, the tax rules governing mutual funds force shareholders to pay taxes on "forced realization income," even though such income does not increase their wealth.

Because mutual fund investors must pay taxes on non-existent gains, while the wealthy can use alternative investment strategies to avoid such taxes, the taxation of mutual funds violates the tax policy objective of vertical equity. To correct the inequities faced by mutual fund investors, the tax law needs to permit low-and middle-income taxpayers to exclude from their income 10 percent of the capital gain dividends they receive each year.

\section{TABLE OF CONTENTS}

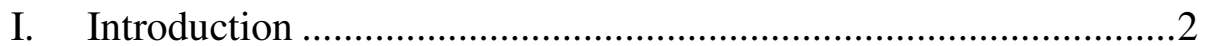

II. Tax Treatment of Mutual Funds.....................................................5

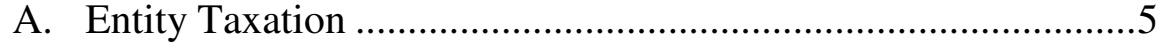

B. Quasi-Pass-Throughs .............................................................

C. Qualifying as a Quasi-Pass-Through .......................................9

III. The Middle Class and Mutual Fund Taxation .........................11

IV. Mutual Fund Shareholders Face an Inequitable Tax Burden ...19

V. Restoring Investment Equity for Middle-Class Investors ............24

A. Fundamental Reforms to Solve InequitiesError! Bookmark not defined.28

\footnotetext{
* Assistant Professor, Loyola University Chicago School of Law. I would like to thank Jeffrey L. Kwall, John Morley, Anne-Marie Rhodes, Spencer Weber Waller ... the participants in the Faculty Workshop at Loyola University Chicago School of Law, the participants in the Seventh Annual Junior Tax Scholars Workshop held at UC Hastings College of Law, the participants at ClassCrits V held at the University of Wisconsin, the participants the Critical Perspectives on Tax Policy Workshop held at the University of Washington . Additional thanks to Jamie Brunson for her support. I can be reached at sbrunson@luc.edu.
} 
B. A Proportionate Response ..................................................25

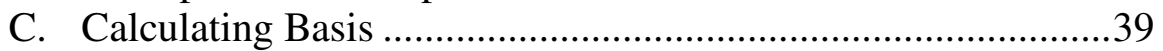

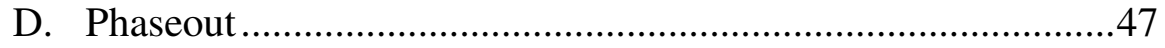

E. Illustrating the Exemption ...................................................51

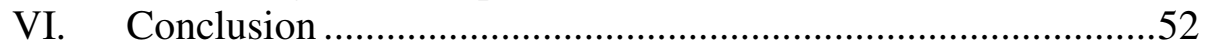

\section{INTRODUCTION}

The rich, it turns out, are different from the rest of us. And not just because they have more money. ${ }^{1}$ They can invest in ways unavailable to the average American. Many have pointed out, for example, the advantages of earning capital gains, which make up a large percentage of wealthy Americans' income, rather than ordinary wage income, which makes up the majority of the income earned by the rest of us. ${ }^{2}$ Their advantages do not end, however, at preferential capital gains rates. The very vehicles available to wealthy investors have tax advantages over the vehicles available to the rest of us. ${ }^{3}$

When the rest of us invest, we do so largely through mutual funds. Nearly half of American households own mutual funds, ${ }^{4}$ far more than own direct investments in stocks or bonds. ${ }^{5}$ In fact, in 2010 , mutual funds represented 23 percent the financial assets held by U.S. households. Mutual funds provide households with a relatively easy

\footnotetext{
${ }^{1}$ See ERnESt Hemingway, The Snows of Kilimanjaro, in THE COMPLETE SHORT STORIES OF ERNEST HEMINGWAY 39, 53 (1998) ("He remembered poor Julian and his romantic awe of them and how he had started a story once that began, 'The rich are different from you and me.' And how some one had said to Julian, Yes, they have more money.").

${ }^{2}$ See, e.g., Paul Krugman, The Social Contract, N.Y. TIMES, Sep. 23, 2011, at A35 ("[P] eople with multimillion-dollar incomes, who typically derive much of that income from capital gains and other sources that face low taxes, end up paying a lower overall tax rate than middle-class workers.").

${ }^{3}$ Such investments include hedge funds and private equity funds. Like mutual funds, they provide investors with diversification, but often require a minimum initial investment of \$1 million or more. Samuel D. Brunson, Taxing Investment Fund Managers Using a Simplified Mark-to-Market Approach, 45 WAKE FOREST L. REV. 79, 84 (2010).

As a result, such investments are simply outside the reach of most households.

${ }^{4}$ INVESTMENT COMPANY INSTITUTE, 2011 INVESTMENT COMPANY FACTBOOK 80 (51st ed. 2011) [hereinafter, ICI FACTBOOK], available at http://www.ici.org/pdf/2011_factbook.pdf. ${ }^{5}$ Alan R. Palmiter \& Ahmed E. Taha, Mutual Fund Investors: Divergent Profiles, 2008 Colum. Bus. L. REV. 934, 941 (2008).
} 
way to diversify their assets. Moreover, the majority of U.S. households can afford to invest in mutual funds: many mutual funds require a minimum investment of $\$ 500$ or less. ${ }^{6}$ As a result, mutual funds appeal largely to moderate-income households. ${ }^{7}$

With such a broad clientele, the mutual fund industry is understandably enormous. At the end of 2010, U.S. mutual funds managed \$13.1 trillion in assets. ${ }^{8}$ This \$13.1 trillion meant that mutual funds owned fully 27 percent of U.S. companies' outstanding stock at the end of $2010 .^{9}$

In light of their ubiquity and importance, a surprisingly small amount of scholarship has examined the taxation of mutual funds. ${ }^{10}$ Perhaps the literature has neglected mutual funds because the tax law treats them as an odd sort of hybrid: not corporations, exactly, but also not partnerships. Instead, they function as a type of quasi-pass-through entity. ${ }^{11}$ As a result of this status, mutual funds generally do not pay an entity-level tax. ${ }^{12}$ To avoid the entity-level tax, though, they must meet stringent rules.

\footnotetext{
${ }^{6}$ See Rob Wherry, SmartMoney Fund Screen / Low Minimum Investments, WALL ST. J., Nov. 13, 2007, at D2 ("We usually nix funds that require new shareholders to pony up more than $\$ 5,000$ when they first buy shares. This week, though, we reduced that amount to just $\$ 500 . ”)$.

${ }^{7}$ Palmiter \& Taha, supra note 5, at 941 ("[M]ost households that own mutual funds have moderate income and wealth.").

${ }^{8}$ ICI FACTBOOK, supra note 4 , at 8.

${ }^{9} \mathrm{Id}$.

${ }^{10}$ For exceptions to this general lack of scholarly attention to the taxation of mutual funds, see generally John Morley, Collective Branding and the Origins of Investment Fund Regulation, 3 VA. L. \& BUS. REV. 341 (2012); John C. Coates IV, Reforming the Taxation and Regulation of Mutual Funds: A Comparative Legal and Economic Analysis, 1 J. Legal AnAlysis 591 (2009), Mitchell L. Engler, A Missing Piece to the Dividend Puzzle: Agency Costs of Mutual Funds, 25 CARDOZO L. REV. 215 (2003) (arguing that mutual fund advisors ignore tax consequences to mutual fund investors); Shawn P. Travis, The Accelerated and Uneconomic Bearing of Tax Burdens by Mutual Fund Shareholders, 55 TAX LAW. 819 (2002) (addressing tax differences between mutual fund investors and direct investors).

${ }^{11}$ See Samuel D. Brunson, Repatriating Tax-Exempt Investments: Tax Havens, Blocker Corporations, and Unrelated Debt-Financed Income, 106 Nw. U. L. REV. 225, 242 (2012) ("Although not true pass-through entities for tax purposes, the tax treatment of mutual funds eliminates the second level of taxation and treats them as quasi-pass-through entities.").

${ }^{12}$ See I.R.C. $\S 11(\mathrm{a})$ (2006) (imposing tax on taxable income of corporations).
} 
The unique rules applicable to mutual funds comprise approximately seven sections of the Internal Revenue Code, ${ }^{13}$ and these rules generally do not play out on the larger canvas of entity taxation. Because of their unique nature, though, the tax law governing mutual funds demands a closer look. With about 51.6 million households owning mutual funds, these few sections of the tax law have a significant impact on the economic life of Americans. As a result of the rules governing mutual funds, shareholders must pay taxes on "forced realization income," even though such income does not increase their wealth.

Because most mutual fund shareholders have moderate income, ${ }^{14}$ these additional tax costs fall most heavily on low- and middle-class taxpayers. The rich do not have to bear these tax costs because they have access to alternative investment strategies, strategies that are not bounded by the tax rules applicable to mutual funds and are generally inaccessible to poorer households. Because mutual fund investors must pay taxes on non-existent gains, while the wealthy can use alternative investment strategies to avoid such taxes, the taxation of mutual funds violates the tax policy objective of vertical equity. ${ }^{15}$ To remedy the vertical equity problem, this Article proposes that, in certain circumstances, low- and middle-income taxpayers be permitted to exclude from their income 10 percent of the "capital gain dividends" "16 they receive each year.

This Article proceeds as follows. Part II explains the advantageous tax treatment of mutual funds and what funds must do to qualify for such treatment. Part III discusses some of the consequences of the mutual fund tax rules for shareholders, and compares the tax treatment of mutual fund shareholders and other types of investors. Part IV looks at these differences through the lenses of fairness and vertical equity. Finding the treatment unfair and inequitable, Part $\mathrm{V}$ then discusses

\footnotetext{
${ }^{13}$ I.R.C. $\$ \S 851-855,860,4982$ (2006).

${ }^{14}$ Twenty-five percent of households that own mutual funds have annual incomes of less than $\$ 50,000 ; 64$ percent have income of less than $\$ 100,000$. ICI FACTBOOK, supra note 4 , at 82 .

${ }^{15}$ Vertical equity considerations underlie the decision to include progressivity in tax rates; put simply, vertical equity concerns hold that taxpayers with a greater ability to pay should pay more in taxes. C. EUGENE STEUERLE, CONTEMPORARY U.S. TAX TAX POLICY 11 (2nd ed. 2008).

${ }^{16}$ A "capital gain dividend" is that portion of a mutual fund's dividend that corresponds to the mutual fund's net capital gain for the year, and that the fund designates as a capital gain dividend. I.R.C. § 852(b)(3)(C) (2006).
} 
how an exemption of part of a shareholder's capital gain dividend would improve the fairness and vertical equity of the tax law and provides a detailed explanation how the exemption should be designed.

\section{TAX TREATMENT OF MUTUAL FundS}

\section{A. Entity Taxation}

In general, the tax law categorizes business entities either as corporations or as partnerships. ${ }^{17}$ The tax regime applicable to corporations differs significantly from that applicable to partnerships. In general, a corporation pays taxes on its income at a top marginal rate of $35 \% .^{18}$ The corporation's shareholders, however, do not pay taxes on corporate income; rather, if and when the corporation pays a dividend, shareholders must include the dividend in their gross income and pay taxes on it. ${ }^{19}$ Although corporate dividends are ordinary income, and historically have been taxed at a shareholder's marginal rate, under current law, qualifying dividends are taxed at a top rate of 15 percent. $^{20}$

Unlike corporations, partnerships do not pay taxes. ${ }^{21}$ Instead, the tax law treats partners as if they had directly earned their share of the partnership's income; ${ }^{22}$ both the amount and the character of the partnership's income pass through to its partners. ${ }^{23}$ As a result, partnerships escape the double taxation that applies to corporations. However, where shareholders do not pay taxes on corporate income until they receive it as a dividend, partners cannot defer their payment of taxes. They include their share of partnership income on their tax return for the year the partnership earns that income, whether or not they receive a distribution of that income from the partnership. ${ }^{24}$

The double taxation of corporate shareholders can be illustrated as follows: assume that John owns 10 percent of the shares

\footnotetext{
${ }^{17}$ Treas. Reg. $\$ 301.7701-2$ (a) (as amended in 2011) (“A business entity with two or more members is classified for federal tax purposes as either a corporation or a partnership.").

${ }^{18}$ I.R.C. $\$ 11$ (2006).

${ }^{19}$ I.R.C. $\$ 301(c)(1)(2006)$.

20 "Qualified dividend income" is eligible to be taxed at the rate applicable to longterm capital gains. I.R.C. $\S 1(\mathrm{~h})(11)$ (2006).

${ }^{21}$ I.R.C. $\$ 701$ (2006) ("A partnership as such shall not be subject to the income tax imposed by this chapter.").

${ }^{22}$ I.R.C. § 702(a) (2006).

${ }^{23}$ I.R.C. $\$ 702(\mathrm{~b})$.

${ }^{24}$ Treas. Reg. $\S 1.702-1$ (a) (as amended in 2005).
} 
of XYZ Inc. In 2011, XYZ Inc. had \$1,000 of taxable income. XYZ Inc. paid $\$ 350$ in taxes, ${ }^{25}$ but John had no tax liability in 2011 as a result of his ownership of XYZ. However, in 2012, XYZ Inc. distributes $\$ 650$ to its shareholders. John receives $\$ 65$ as his share of the dividend. Provided the dividend qualifies as "qualified dividend income," he will pay about $\$ 9.75$ in taxes. Of the $\$ 100$ of corporate pre-tax income allocable to John's shares, John will end up with $\$ 55.25$ after taxes.

If $\mathrm{XYZ}$ were instead a partnership, XYZ would pay no taxes on its receipt of $\$ 1,000$ in 2011. Instead, John would pay taxes on his 10 percent distributive share in 2011. If the partnership's income was ordinary income and John paid taxes at the top marginal rate, he would owe $\$ 35$ in taxes in 2011, whether or not he received his $\$ 100$ from the partnership. At some point, the partnership would presumably distribute John's $\$ 100$ to him, at which point he would have no additional tax liability. After taxes, John would have $\$ 65$ of the $\$ 100$ of partnership income allocable to his partnership interest.

The double taxation of corporate income-once at the corporate level, then again when distributed to shareholders-concerns many policymakers. They argue that this double taxation discourages investors from investing in corporate equity, instead putting their money into lower-taxed investments, thus eroding the corporate tax base. ${ }^{26}$ And, in fact, data indicates that economic activity by passthrough entities has increased much more rapidly than economic activity by taxable corporations. ${ }^{27}$

The distortions caused by the double taxation of corporate profits do not limit themselves to investors, however. Double taxation also affects how corporations raise money. A corporation pays taxes

\footnotetext{
${ }^{25}$ Actually, because corporate tax rates are graduated, a corporation with only $\$ 1,000$ in income would not pay taxes at a 35 percent rate. I.R.C. § 11(b). Arguably such graduated rates are inequitable and subject to abuse, and should be repealed in any event. See Jeffrey L. Kwall, The Repeal of Graduated Corporate Tax Rates, 131 TAX NOTES 1395, 1397 (2011). For simplicity's sake, I will ignore the graduated corporate tax rates and treat all corporate income as if it were subject to the top rate of 35 percent.

${ }^{26}$ See, e.g., THE PRESIDENT'S AdVISORY PANEL ON FEDERAL TAX REFORM, SimPle, FAIR, AND PRO-GROWTH: PROPOSALS TO FIX AMERICA'S TAX SYSTEM 99 (2005) [hereinafter ADVISORY PANEL, PROPOSALS] ("The double tax on corporate earnings ... discourages investments in corporate equity in favor of other investments that are not taxed as heavily.").

${ }^{27}$ See Heather M. Field, Checking In On "Check-the-Box", 42 LOY. L.A. L. REV. 451, 493-94 (2009).
} 
on its income; to the extent it pays that income out to shareholders as a dividend, the shareholders owe taxes on their dividends, while the corporation gets no deduction for dividends paid. ${ }^{28}$ But corporations have other paths available for raising capital-besides issuing equity, corporations can borrow money. Borrowing eliminates the double taxation problem; even though lenders pay taxes on interest income at ordinary rates, "[i]ncome from debt-financed corporate investment . . . is largely untaxed at the corporate level because corporations may deduct interest payments." 29

In spite of the inefficiencies of and distortions caused by the corporate income tax, though, lawmakers have neither eliminated it nor fully integrated it with the individual income tax. In fact, lawmakers have worked to prevent the erosion of the corporate tax base through taxpayer self-help. ${ }^{30}$ Most notably, in 1987, Congress passed the publicly traded partnership rules. ${ }^{31}$ Congress worried that corporations would yield to the pressure to disincorporate and avoid a second level of taxation. ${ }^{32}$ To relieve this pressure, Congress prevented certain partnerships from enjoying the benefits of passthrough taxation. The publicly traded partnership rules provide that the tax law will treat certain partnerships as if they were corporations. ${ }^{33} \mathrm{By}$ preventing certain entities from enjoying pass-through treatment, Congress could maintain a certain level of corporate tax revenues. ${ }^{34}$

\section{B. Quasi-Pass-Throughs}

Notwithstanding its desire to preserve the corporate tax base, Congress created and has maintained a special taxing regime

${ }^{28}$ Eric M. Zolt, Corporate Taxation After the Tax Reform Act of 1986: A State of Disequilibrium, 66 N.C.L. REV. 839, 860 (1988).

${ }^{29}$ ADVISORY PANEL, PROPOSALS, supra note 26, at 99.

${ }^{30}$ Cf. Zolt, supra note 28 , at 875 ("Tolerating self-help integration, however, is hardly a rational approach to the problems created by the imbalance in the corporate tax system.").

${ }^{31}$ Rebecca S. Rudnick, Who Should Pay the Corporate Tax in a Flat Tax World?, 39 CASE W. RES. 965, 977 (1989).

${ }^{32}$ Id. ("Congress expanded the scope of the corporate tax system by including publicly traded partnerships among the firms taxed as corporations, in order to relieve the presumed pressure to disincorporate.").

${ }^{33}$ I.R.C. § 7704(a) (2006).

${ }^{34}$ There may be defensible reasons in addition to raising revenue to hesitate from fully integrating the corporate and individual income taxes. Professor Jeffrey Kwall argues, for example, "that equity and efficiency may be better served" by maintaining a corporate income tax, which provides sufficient government revenue while allowing the government to keep individual tax rates lower. Jeffrey L. Kwall, The Uncertain Case Against the Double Taxation of Corporate Income, 68 N.C.L. REV. 613, 618 (1990). 
applicable to mutual funds. A mutual fund that meets certain requirements can elect to be taxed as a "regulated investment company." 35 Like a partnership, these electing mutual funds can avoid paying an entity-level tax but, but mutual fund shareholders do not get full pass-through treatment. Instead, mutual funds inhabit the world of quasi-pass-throughs. $^{36}$

To qualify for the special tax treatment, a mutual fund must be a domestic corporation. ${ }^{37}$ As such, it pays taxes at the applicable corporate rates, just like ordinary domestic corporations. ${ }^{38}$ However, a mutual fund pays taxes based on its "investment company taxable income." 39 A mutual fund calculates its investment company taxable income in a manner similar to a corporation's calculation of its taxable income, but with several differences. ${ }^{40}$ The most significant difference is that a qualifying mutual fund can deduct the dividends it pays as it determines its investment company taxable income. ${ }^{41}$ Like corporate shareholders, and unlike investors in pass-through entities, mutual fund shareholders pay taxes on the dividends they receive in the year they receive the dividends, not necessarily the year the mutual fund earned the income. However, to preserve the feel of pass-through taxation, mutual funds shareholders pay taxes at the preferential longterm capital gain rates on the portion of their dividend attributable to the mutual fund's net capital gains and qualified dividend income. ${ }^{42}$

Mutual funds' dividends paid deduction essentially eliminates corporate double taxation. Assume that, instead of a partnership or ordinary corporation, XYZ is a qualifying mutual fund. In 2011 it

\footnotetext{
${ }^{35}$ I.R.C. $\$ 851($ b). The I.R.C. does not ever refer to "mutual funds"; the rules discussed in this Article technically apply only to "regulated investment companies." Nonetheless, for simplicity's sake, this Article will refer to mutual funds rather than regulated investment companies. Moreover, because the tax law does not distinguish between closed-end and open-end funds, this Article will refer to both as "mutual funds."

${ }^{36}$ Quasi-pass-through entities include not only mutual funds, but also certain other passive investment vehicles, including real estate investments trusts and real estate mortgage investment conduits. Joseph M. Dodge and Jay A. Soled, Debunking the Basis Myth Under the Income Tax, 81 IND. L.J. 539, 584 n.237 (2006).

${ }^{37}$ I.R.C. $\S 851(\mathrm{a})$.

${ }^{38}$ I.R.C. $\$ 852(\mathrm{~b})(1)$.

${ }^{39} \mathrm{Id}$.

${ }^{40}$ Id. $\S 852(\mathrm{~b})(2)$.

${ }^{41} I d . \$ 852(\mathrm{~b})(2)(\mathrm{D})$. Mutual funds also do not include their net capital gain in their calculation of taxable income. Id. $\S 852(\mathrm{~b})(2)(\mathrm{A})$.

${ }^{42} I d . \S 852(\mathrm{~b})(3)(\mathrm{B})$.
} 
earned $\$ 1,000$ of income. On December 31, 2011, it paid a dividend of $\$ 1,000$ to its shareholders. John received $\$ 100$ as his share of XYZ's dividend. In calculating its income, $X Y Z$ had a deduction of $\$ 1,000$ that it used to offset its $\$ 1,000$ of income. As a result, XYZ had no investment company taxable income for 2011, and no tax liability. John had to include his $\$ 100$ dividend in his income and pay taxes on that $\$ 100$. As with a partnership, XYZ's income faced only one level of taxation.

Why provide mutual fund investors with this single level of taxation? On the surface, it allows mutual fund shareholders to face tax consequences similar to those that would apply if they invested directly in the mutual fund's underlying portfolio. If they invested directly in the securities that their mutual fund holds, they would only pay taxes on dividends they received and gains from the sale of those securities. The imposition of an intermediary should not disadvantage investors, especially where the intermediary is necessary for those investors to achieve portfolio diversification. ${ }^{43}$

\section{Qualifying as a Quasi-Pass-Through}

To enjoy the benefits of this quasi-pass-through tax regime, the tax law places certain restrictions and obligations on mutual funds. These restrictions and obligations fall into three broad categories: an administrative requirement, an income-and-assets requirement, and a distribution requirement. The administrative requirement is relatively easy to meet. Under it, a mutual fund must be organized as a corporation, register under the Investment Company Act of 1940 (the "1940 Act"), and file an election with the IRS. ${ }^{44}$ Though administrative, this registration under the 1940 Act creates real obligations for and imposes significant regulation on a mutual fund. ${ }^{45}$

The income-and-assets requirement substantively affects a mutual fund's day-to-day activities. The income side of this requirement says that at least 90 percent of a mutual fund's income must derive from specified sources, including dividends, interest, foreign currency, gains on the sale of securities, and other income

\footnotetext{
${ }^{43}$ See infra notes 51-57 and accompanying text.

${ }^{44}$ I.R.C. $\$ 851(\mathrm{a})(1)$.

${ }^{45}$ See Coates, supra note 10, at 621 ("The [1940 Act] is heavily proscriptive. It requires and forbids numerous actions in the operation of regulated funds."). The registration requirement is, however, beyond the scope of this Article.
} 
related to its investment in securities. ${ }^{46} \mathrm{~A}$ mutual fund cannot derive more than 10 percent of its income from other sources, including active businesses and commodities.

Along with limitations on the types of income they can earn, mutual funds also face limitations on the types of assets they can own. Broadly speaking, the asset requirement mirrors the income requirement (that is, mutual funds can own the types of assets that produce qualifying income), but serve a different purpose than the income side of the requirement. Half of a mutual fund's assets must consist of cash, government securities, and other securities. However, no single issuer in this "other securities" category can make up more than five percent of the value of the mutual fund's portfolio, and the mutual fund cannot own more than ten percent of the voting stock of any single issuer. ${ }^{47}$ Although these specific restrictions only apply to half of a mutual fund's assets, mutual funds are prohibited from investing more than 25 percent of the total value of their assets in one issuer or in two or more issuers in the same trade or business. ${ }^{48}$

Where the income side of this requirement forces mutual funds to invest in select passive assets, the asset side forces them to diversify. A mutual fund cannot be overly-exposed to a single company, or even a single trade or business. At the same time, it faces significant limitations on its ability to hold a majority share in companies. Instead, to qualify as a quasi-pass-through, it must invest passively and in a diversified manner.

Finally, mutual funds face a distribution requirement. To qualify for the dividends-paid deduction, every year a mutual fund must pay dividends constituting at least 90 percent of its investment company taxable income to shareholders. ${ }^{49}$ Generally, however, mutual funds will distribute far more of their income. If a mutual fund distributes less than 98 percent of its ordinary income and 98.2 percent of its capital gain income during the year, it must pay a 4-percent excise tax on such shortfall. ${ }^{50}$ Effectively, then, every year, a mutual fund distributes all of its income to its shareholders.

\footnotetext{
${ }^{46} I d . \S 851(\mathrm{~b})(2)$.

${ }^{47}$ Id. $\S 851(\mathrm{~b})(3)(\mathrm{A})$.

${ }^{48}$ Id. $\$ 851(\mathrm{~b})(3)(\mathrm{B})$.

${ }^{49}$ Id. $\S 852(\mathrm{a})(1)$.

${ }^{50}$ Id. $\S 4952(\mathrm{a})$.
} 
III. The Middle Class AND Mutual Fund TAXATION

Mutual funds provide investors with "the benefits of professional investment advice, asset management, and risk diversification." 51 They do so in a relatively affordable manner, however-the minimum required investment to purchase a mutual fund is typically around $\$ 1,000 .{ }^{52}$ Hedge funds, on the other hand, often require minimum initial investments of $\$ 1$ million, making hedge fund investments impossible for any but the richest individuals. ${ }^{53}$ Similarly, to invest directly in a diversified portfolio of stocks and bonds similar to that provided by a mutual fund, an investor would need enough money in savings with no immediate need to spend that money. Mutual funds, on the other hand, provide their shareholders with exposure to a large basket of stocks. ${ }^{54}$ By pooling the investments of their thousands of shareholders, and providing shareholders with proportionate exposure to each of the stocks, even an investor with limited assets can enjoy the benefits of broad diversification. In addition to the expense of assembling a diversified portfolio, moreover, managing such a portfolio would require significant knowledge and time commitments that an individual investor may not have.

As a result, mutual funds understandably attract "the least sophisticated members of the investing public." 55 Their benefits largely accrue to the middle class: the majority of mutual fund shareholders have household incomes of less than $\$ 100,000$, and a quarter have household incomes of less than $\$ 50,000 .^{56}$ The wealthy

\footnotetext{
${ }^{51}$ Consuelo L. Kertz \& Paul J. Simko, Mutual Fund Investing and Tax Uncertainty: The Need for New Disclosures, 7 STAN. J.L. BuS. \& Fin. 103, 103 (2001).

${ }^{52}$ Investment Company Institute, The Difference Between Mutual Funds and Hedge Funds, available at http://www.ici.org/investor_ed/brochures/faqs_hedge (last visited June 8, 2012).

${ }^{53}$ Vikas Agarwal, Nicole M. Boyson, \& Narayan Y. Naik, Hedge Funds for Retail Investors? An Examination of Hedged Mutual Funds, 44 J. Fin. \& Quantitative Analysis 273, 274 (2009). In fact, mutual funds that use hedge fund strategies and attempt to replicate their returns often have a minimum investment of only $\$ 5,000$. Id.

${ }^{54}$ Actively managed equity mutual funds own a median of 65 stocks. Marcin Kacperczyk, Clemens Sialm, \& Lu Zheng, On the Industry Concentration of Actively Managed Equity Mutual Funds, 55 J. FIN. 1983, 1987 (2005).

${ }^{55}$ Martin J. Aronstein, The Decline and Fall of the Stock Certificate in America, $1 \mathrm{~J}$. COMP. CORP. L. \& SEC. REG. 273, 279 (1978).

${ }^{56}$ See supra note 14.
} 
can afford to pay someone to manage their portfolios, ${ }^{57}$ can make the minimum investment in a hedge fund, and have access to other methods of diversification, while the middle-class cannot.

Congress intended for mutual funds to have this middle-class focus. Under the Revenue Act of 1926, the government taxed "associations, joint-stock companies and insurance companies" as corporations. ${ }^{58}$ Though this threatened to tax investment trusts (the precursors to modern mutual funds) as corporations, rather than treating them as untaxed pass-through entities, investment trusts relied on case law that provided that a trust "would not be separately taxed as a corporation if it was not carrying on a business." 59 Until 1935, such trusts claimed that managing a passive investment portfolio did not rise to the level of carrying on a business. ${ }^{60}$ But then, in Morrissey $v$. Commissioner, the Supreme Court held that an investment trust was an association carrying on a business. ${ }^{61}$ As such, it was subject to entitylevel taxation.

Taxing mutual funds made them much more expensive; had that rule persisted, the middle- and lower classes would not have had access to affordable diversification or investment management. To give these investors access to affordable investments, Congress created the quasi-pass-through regime to return mutual funds to their pre-1935 tax status. ${ }^{62}$

1. Mutual Funds and Forced Realization Income

In spite of the fact that qualifying mutual funds do not face an entity-level tax, mutual fund investments face heavier taxation than non-mutual fund investments. This higher taxation results largely from mutual funds' distribution obligations, combined with the fact that the

\footnotetext{
${ }^{57}$ See Mark J. Roe, Political Elements in the Creation of a Mutual Fund Industry, 139 U. PA. L. REV. 1469, 1483 (1991).

${ }^{58}$ Revenue Act of $1926 \S 2(\mathrm{a})(2)$, Pub. L. No. 69-20, 44 Stat. 9, 9.

${ }^{59}$ Roe, supra note 57 , at 1481 .

${ }^{60}$ Morrissey v. Commissioner, 296 U.S. 344, 348 (1935).

${ }^{61}$ Id. at 360.

${ }^{62}$ Roe, supra note 57, at 1483 ("Tax doctrine was reconciled with the goal of giving the middle-class collective access to professional investment management by returning to the view that picking a fragmented portfolio was not really a business after all.").
} 
law requires mutual funds to redeem a shareholder's shares within a week of receiving her redemption request. ${ }^{63}$

Unless it has sufficient cash reserves, a mutual fund generally must sell some of its securities when it decides to pay a dividend or when shareholders request redemption. ${ }^{64}$ To the extent the mutual fund realizes a gain on the sale, moreover, it must include that gain in its investment company taxable income. This, in turn, means that it must distribute a larger dividend to its shareholders to qualify for quasipass-through treatment and to avoid an excise tax. This larger dividend does not, however, increase its remaining shareholders' wealth. While shareholders have additional cash as a result of the dividend, the increase in their cash corresponds with a decrease in the net asset value of the fund. In essence, any time a mutual fund has to sell securities to pay dividends or meet its redemption requirement, it can create taxable income for its shareholders without creating any concomitant value for them.

To some extent, the tax law permits mutual funds to shield their shareholders from this phantom taxable income as it relates to dividends. Mutual funds can provide their shareholders with the option to have their dividends reinvested in the fund's shares rather than paid in cash. As long as shareholders could have received the dividends as cash, the reinvestment will count toward the 90 percent and 98 percent distribution requirements. ${ }^{65}$ As a result, if all of a mutual fund's shareholders elect the fund's dividend reinvestment plan, the fund

\footnotetext{
${ }^{63}$ See Robert C. Illig, What Hedge Funds Can Teach Corporate America: A Roadmap for Achieving Institutional Investor Oversight, 57 AM. U.L. REV. 225, 294 ("Open-end mutual funds ... must be ready to redeem their shares on a daily basis and to pay redeeming shareholders within seven days of receiving a request."). ${ }^{64}$ See, e.g., Jason T. Greene \& Charles W. Hodges, The Dilution Impact of Daily Fund Flows on Open-End Mutual Funds, 65 J. FIN. ECON. 131, 131-32 (2002) ("The fund itself must either engage in costly trade or alter its cash position in response to mutual fund traders' exchanges.").

${ }^{65}$ Technically, the process works like this: to qualify as a regulated investment company, at least 90 percent of a mutual fund's investment company taxable income must qualify for the deduction for dividends paid. I.R.C. $\S 852(a)(1)$. To qualify for the deduction, the dividend must constitute "property" under I.R.C. $\S 301$. Id. $\S \S$ 562(a), 316(a). For these purposes, the tax law generally does not treat a corporation's distribution of its own shares as a distribution of property. Id. $\S 305(\mathrm{a})$. If, however, the distribution can by paid either in property or in the corporation's own stock, and shareholders can elect whether they want to receive property or stock, a distribution of stock will qualify as a dividend. Id. $\S 305(\mathrm{~b})(1)$; Treas. Reg. $\S \S$ 1.305-1(b)(2) (as amended in 1993), 1.305-2(b), Ex. 2 (as amended in 1973).
} 
does not have to sell any shares to pay its dividends. It only has to issue new shares, and that issuance does not create phantom taxable income for its shareholders. ${ }^{66}$

A mutual fund cannot require its shareholders to choose the dividend reinvestment plan, though. Presumably, then, mutual funds will have pay some amount of their dividends in cash each year. Moreover, mutual funds have no similar way to limit the phantom taxable income that arises for remaining shareholders when a different shareholder redeems her shares. Imagine a mutual fund with three shareholders. Each purchases a share of the mutual fund for $\$ 10$; the fund then invests the $\$ 30$ in three shares of $\mathrm{ABC}$ stock. ${ }^{67}$ After one year, $\mathrm{ABC}$ has not paid a dividend, but the value of its stock has increased from $\$ 10$ to $\$ 15$. In spite of the increase in value of its assets, the mutual fund has not realized any income, however, and has no distribution requirement. Because of its increased net asset value, though, the mutual fund's shares are now worth $\$ 15$ each. If one of the mutual fund's shareholders decides to redeem her shares, the mutual fund must buy it back for $\$ 15$. To do so, the mutual fund will sell one $\mathrm{ABC}$ share; the redeeming shareholder will have $\$ 5$ of long-term capital gain. $^{68}$

The economic position of the remaining two shareholders does not change as a result of the exiting shareholder. Their tax liabilities, however, do. When the mutual fund sold the share of ABC stock, it, too, realized a \$5 long-term capital gain. To qualify for its taxadvantaged status and to avoid an excise tax, it must distribute that gain to its shareholders; therefore, it will pay a dividend of $\$ 2.50$ per share to the remaining two shareholders. Its net asset value will drop from $\$ 30$ to $\$ 25$, and the shareholders will each have a mutual fund share worth $\$ 12.50$ and cash worth $\$ 2.50$. However, they must include the $\$ 2.50$ in their gross income and pay taxes on it; notwithstanding the fact the dividend did nothing to improve the economic condition of the remaining shareholders, the tax rules governing mutual funds created a tax liability for them.

\footnotetext{
${ }^{66}$ Even if all shareholders elect to reinvest their dividends, though, they are still taxable on their reinvested dividends.

${ }^{67}$ For simplicity's sake, I will ignore the mutual fund diversification requirements for purposes of this hypothetical.

${ }^{68}$ She has a basis of $\$ 10$ in her share, and she realizes $\$ 15$. As a result, her gain is $\$ 5$. I.R.C. $\S 1001$ (a) (2006). Because her mutual fund share is a capital asset which she has held for longer than one year, her gain is long-term capital. Id. $\S \S 1221,1222$.
} 
A wealthy investor can avoid this "forced realization income." No tax liability would exist if she invested directly in the underlying portfolio of securities. The realization rule requires that she sell her securities before she owes tax on the gains. ${ }^{69}$ As long as the investor continues to hold her securities, others' purchases and sales of securities - even securities identical to those she holds—will not affect her tax liability. The investor would only be subject to taxation when she received dividends and when she sold her shares.

Hedge fund investors, on the other hand, seem to face the same forced realization income problem as mutual fund investors. Although most hedge funds limit their investors' ability to redeem, ${ }^{70}$ ultimately, hedge fund investors can sell their interests back to the fund at net asset value. Like mutual funds, if hedge funds do not have sufficient cash to redeem their investors, they must sell securities to get the cash. Because hedge funds are treated as partnerships for tax purposes, hedge fund investors must pay taxes on their share of hedge funds' gains. ${ }^{71}$ Moreover, unlike mutual funds, where shareholders can demand that their dividends be paid in cash, hedge funds have no obligation to distribute gains to their investors. ${ }^{72}$ In this instance, then, hedge funds appear at least as expensive as mutual funds for tax purposes.

Hedge funds can avoid allocating this forced realization income to their remaining partners, though. Partnerships do not have to allocate gains in a strictly pro rata manner; provided their allocations have substantial economic effect, the partnership agreement determines each partner's distributive share. ${ }^{73}$ With this

\footnotetext{
${ }^{69}$ I.R.C. § 1001(a); see Jeffrey L. Kwall, When Should Asset Appreciation Be Taxed?: The Case for a Disposition Standard of Realization, 86 IND. L.J. 77, 79 (2011) ("The U.S. income tax . . has always embraced a realization requirement, thereby deferring the taxation of asset appreciation until the occurrence of a realization event (normally, a sale or exchange of the appreciated property).”).

${ }^{70}$ Often, hedge funds require investors to provide advance notice to redeem their interests, only permit redemptions on certain dates, and/or limit the total percentage of the fund that it will redeem at any given redemption date. See, e.g., Investor Protection Implications of Hedge Funds: Before the S. Comm. on Banking, Housing and Urban Affairs 2 (2003) (testimony of William H. Donaldson, Chairman, U.S. Securities and Exchange Commission). These restrictions severely limit the liquidity of hedge fund interests.

${ }^{71}$ Alan L. Kennard, The Hedge Fund Versus the Mutual Fund, 57 TAX LAw. 133, 142 (2003).

${ }^{72} \mathrm{Id}$.

${ }^{73}$ I.R.C. § 704(a), (b)(2) (2006).
} 
flexibility, many hedge fund agreements include a "stuffing" allocation. $^{74}$

When a hedge fund investor redeems her shares, the hedge fund pays her an amount equal to the shares' net asset value. Without a stuffing allocation, she pays taxes on the difference between the amount she receives and her basis in her hedge fund interest. ${ }^{75}$ She treats the redemption proceeds as capital gain. ${ }^{76}$ Because the hedge fund had to sell securities to fund the redemption proceeds, however, it would need to allocate to the remaining shareholders their share of the gains, and they would owe taxes on those gains.

With a stuffing allocation, however, the hedge fund can allocate the realized gain to the departing partner immediately before her departure so that her basis in her interests equals the fair market value of those interests. ${ }^{77}$ Now she owes no taxes on the redemption proceeds because her basis is the same as her redemption proceeds. However, she owes taxes on the realized gains that the fund allocated to her. ${ }^{78}$ Because the amount she includes in gross income and the character of the income is identical either way, the stuffing provision does not increase the withdrawing partner's tax liability, thus leaving her indifferent to its existence. But because the realized gains are allocated away from the remaining partners, they owe no taxes as a result of the withdrawal of the partner. As such, they can avoid paying taxes on forced realization income in a way that mutual fund investors cannot. ${ }^{79}$ The flexibility of partnership taxation provides better tax treatment for wealthy investors than other investors can achieve.

\section{Other Tax Disadvantages of Mutual Funds}

\footnotetext{
${ }^{74}$ Brian E. Ladin, James M. Lowy, \& William S. Woods II, Hedge Fund Stuffing Allocations: A Path Through the Maze, 121 TAX NoTES 925, 926 (2008).

${ }^{75}$ I.R.C. $\S 731$ (a) (2006).

${ }^{76} \mathrm{Id}$.

${ }^{77}$ Ladin, Lowy \& Woods, supra note 74, at 926.

${ }^{78} \mathrm{Id}$.

${ }^{79}$ It is worth noting that, although not unusual, stuffing allocation are controversial, however. Critics argue that these allocations lack substantial economic effect. See, e.g., Joseph DiSciullo, IRS, Treasury Focused on "Stuffing Allocations," Officials Say, 125 TAX NOTES 67, 67 (2009). If they have no substantial economic effect, the partnership agreement must be ignored and, instead, gains must be allocated according to partners' interest in the partnership. I.R.C. $§ 704(b)$. If stuffing allocations do not work, investors who stay in hedge funds face the same tax disadvantages as investors who stay in mutual funds when another investor withdraws.
} 
In addition to paying taxes on forced realization income, mutual fund shareholders face issues of tax overhang and the inability of losses to flow through mutual funds. Tax overhang causes a mutual fund shareholder may owe taxes on gains from which she will never benefit. Mutual funds must pay dividends at least annually, ${ }^{80}$ and each taxable mutual fund shareholder must pay taxes on any distributions she receives. ${ }^{81}$ A potential shareholder can, however, purchase her shares whenever she wants, which means that she may accidentally buy into a tax overhang. That is, a shareholder owes taxes on her share of the mutual fund's distribution whether she has been a shareholder for one day or one year. When she buys a share of the fund, however, she buys it at net asset value. ${ }^{82}$ If she purchases her share the day before a dividend, however, part of the share's net asset value includes the following day's distribution. ${ }^{83}$ When she receives the dividend, the value of her share will drop by the amount of the dividend. But even though the dividend only constitutes a return of capital to the new shareholder, she must nonetheless pay taxes on her receipt of the dividend. $^{84}$

The tax law treats mutual fund shareholders worse than other diversified investors with respect to losses. Generally, an individual can deduct her losses on the sale of securities against her capital gains, plus $\$ 3,000$ of ordinary income. ${ }^{85}$ If her capital losses exceed her capital gains, she can carry the losses forward until she can use them. ${ }^{86}$

An investor who directly owns securities can use her capital loss deductions to reduce her taxable income. To the extent she has capital losses, she uses them to offset her capital gains for the year. And to the extent her losses exceed her gains for a year, she carries them forward until she can use them. Similarly, capital losses pass

\footnotetext{
${ }^{80}$ I.R.C. $\S 852(\mathrm{a})(1)(2006)$.

${ }^{81}$ See, e.g., I.R.C. $\$ 852(\mathrm{~b})(3)(\mathrm{A})$.

${ }^{82}$ Jerry W. Markham, Mutual Fund Scandals-A Comparative Analysis of the Role of Corporate Governance in the Regulation of Collective Investments, 3 HASTINGS BUS. L.J. 67, 74 (2006).

${ }^{83}$ Kertz \& Simko, supra note 51, at 110.

${ }^{84} I d$. Assume that she purchased a share of the mutual fund for $\$ 10$. The next day, the fund paid a dividend of $\$ 1$ per share. The shareholder would now have a mutual fund share worth $\$ 9$ and $\$ 1$ cash-or, if she received the dividend pursuant to a dividend reinvestment plan, she would have $\$ 10$ worth of shares in the mutual fund-but still she would owe taxes on the $\$ 1$ she received. Id.

${ }^{85}$ I.R.C. $\S 1211$ (b).

${ }^{86}$ Id. $\S 1212(\mathrm{~b})(1)$.
} 
through partnerships, allowing partners to deduct such losses, not only against the gains that pass through the partnership, but against any capital gains they have during the year.

Capital losses do not, however, pass through mutual funds. Instead, the mutual fund uses its capital losses to offset its capital gains in calculating its investment company taxable income. To the extent its capital losses exceed its capital gains, it carries those losses forward. ${ }^{87}$ This means, effectively, that if an individual owns one share each of two mutual funds and one ends the year with a $\$ 10$ per share capital loss, while the other ends the year with a $\$ 5$ per share capital gain, the first mutual fund's net asset value will fall by $\$ 10$, and it will not pay a dividend, while the second mutual fund will pay a dividend of $\$ 5$. The shareholder will owe taxes on the $\$ 5$ dividend, and the $\$ 10$ loss from her other investment will not offset her obligation, even though she has a net loss on her investments. ${ }^{88}$ Moreover, an individual with a net capital loss can deduct it against up to $\$ 3,000$ if she held the securities directly or through a partnership. A mutual fund, however, cannot deduct its capital losses against ordinary income. ${ }^{89}$ Unlike wealthy investors, then, mutual fund investors are limited as to their ability to fully take advantage of their losses.

3. There Is No Policy Reason Underlying These Inequities Though it appears inequitable, the additional tax cost to mutual fund investors could be justified if it resulted from some additional benefit to the investors. There is no evidence, however, that Congress deliberately introduced these additional tax costs as the price of investing in mutual funds. Rather, the rules tried to "put[] fund shareholders on a par with direct investors in securities [while] ensur[ing] that a mutual fund would be an investment company, rather than an operating company." 90 Secondarily, Congress wanted to

\footnotetext{
${ }^{87}$ Id. $\S 1212(\mathrm{a})(3)(\mathrm{A})$.

${ }^{88}$ While these tax consequences are worse than she would face if she owned the securities directly or through a partnership, they could be even worse. Prior to the Regulated Investment Company Modernization Act of 2010, P.L. 111-325 (2010), a mutual fund could carry only carry the loss forward for up to eight years following the loss year. Joint Committee on Taxation, Technical Explanation of H. R.

4337, the "Regulated Investment Company Modernization Act of 2010," for Consideration on the Floor of the House of Representatives 3 (2010).

${ }^{89}$ I.R.C. $§ 1211(\mathrm{a})$.

${ }^{90}$ Mathew P. Fink, The Revenue Act of 1936: The Most Important Event in the History of the Mutual
} 
protect investors from overly-risky bets. ${ }^{91}$ Mutual funds themselves may have agreed to this regulation to bolster the public's confidence in the mutual fund industry. ${ }^{92}$ The additional tax costs of mutual funds as compared with direct portfolio investment does not advance Congress's principal purpose in enacting the mutual fund tax rules. Rather, it violates that purpose: the additional tax cost reduces the similarity between direct investment and indirect investment through mutual funds. Similarly, none of these tax costs effect the secondary purposes of reducing risk or otherwise functioning to bolster public confidence in mutual funds.

Moreover, to the extent that mutual fund shareholders should pay for the benefits afforded by mutual fund taxation, there is no reason they should pay through higher tax costs. Mutual fund shareholders already pay a variety of fees to invest in mutual funds. ${ }^{93}$ To the extent that mutual fund shareholders pay to enjoy the benefits of the mutual fund form, these fees, rather than additional tax cost, constitute that cost. Rules that create additional tax cost may be justifiable when serves a compelling purpose. But where the additional cost serves no purpose, or the purpose could better be accomplished through other means, the tax rules should be changed.

\section{Mutual Fund SHAREHOLdERS FACE AN INEQUiTABLE TAX BURDEN}

As discussed above, the current tax treatment of mutual fund investors is worse than the treatment of direct portfolio investors and investors in private investment funds. ${ }^{94}$ Traditional tax policy evaluates fairness using two principles: horizontal and vertical equity. ${ }^{95}$ Horizontal equity holds that similarly-situated persons should

Fund Industry, FIN. HIST., Fall 2005, at 17-18.

${ }^{91} I d$. at 18.

${ }^{92}$ See Morley, supra note 10, at 380 ("The industry sought regulation to ensure that the industry presented a simple and standardized set of options to the investing public.").

${ }^{93}$ Mutual fund shareholders may directly pay sales charges on purchasing shares. In addition, the mutual fund pays its investment advisor $12 \mathrm{~b}-1$ fees and fund servicing and operating expenses. Shareholders indirectly bear these costs. See John Howat, Compensation Practices for Retail Sales of Mutual Funds: The Need for Transparency and Disclosure, 12 FORDHAM J. CORP. \& FIN. L. 685, 687 (2007).

${ }^{94}$ See supra Section III.

${ }^{95}$ Susan Pace Hamill, An Argument for Tax Reform Based on Judeo-Christian Ethics, 54 ALA. L. REV. 1, 46-47 (2002). 
face approximately the same tax burden. ${ }^{96}$ Vertical equity, on the other hand, "means that taxpayers with higher incomes should pay tax at higher rates." 97 While vertical equity considerations generally underlie the tax law's progressivity in general, we can also scrutinize individual provisions and regimes to evaluate whether those provisions meet the norm of vertical equity. ${ }^{98}$

The current tax treatment of mutual fund investors clearly meets the horizontal equity standard. All mutual fund investors pay taxes on their share of the fund's income for the year, unless they hold their mutual fund shares through a tax-advantaged retirement account. ${ }^{99}$ But satisfying horizontal equity concerns without also satisfying vertical equity concerns does not necessarily create a fair tax regime. Vertical equity "is key for tax policymaking." 100

The wealthy investors face a different tax burden than middleclass investors does not, however, itself necessitate a change in the tax law. Any change would necessarily create losers who had structured their investments based on prior law. ${ }^{101}$ Moreover, any change aimed at closing the gap between the tax treatment of mutual fund investors and wealthy investors would increase the complexity of the tax law. Complexity increases both the cost of complying with and the cost of enforcing the tax law. ${ }^{102}$ In addition, any change that tried to reduce the imposition of taxes on mutual fund investors' forced realization income would presumably decrease governmental revenue. Of course,

\footnotetext{
${ }^{96}$ See, e.g., Michael J. Graetz, Taxing International Income: Inadequate Principles, Outdated Concepts, and Unsatisfactory Policies, 26 BROOKLYN J. INT'L L. 1357, 1402 (2001) (horizontal equity requires "similar treatment of taxpayers similarly situated").

${ }^{97}$ Donna M. Byrne, Progressive Taxation Revisited, 37 ARIZ. L. REV. 739, 759 (1995).

${ }^{98}$ See, e.g., Danshera Cords, Charitable Contributions for Disaster Relief: Rationalizing Tax Consequences and Victim Benefits, 57 CATH. U.L. REV. 427, 455 (2008) (stating that the larger charitable deduction for high-income taxpayers violates vertical equity); Andrew D. Pike, No Wealthy Parent Left Behind: An Analysis of Tax Subsidies for Higher Education, 56 AM. U.L. REV. 1229, 1250-51 (2007) (stating that education tax credits disproportionately benefit high-income parents and violates vertical equity).

${ }^{99}$ For a discussion of investing in mutual funds through tax-advantaged retirement accounts see infra notes 113-125.

${ }^{101}$ Michael Doran, Legislative Compromise and Tax Transition Policy, 74 U. CHI. L. REV. 545, 545 (2007) ("The question presents itself with particular force because of the stubborn fact that legal transitions produce winners and losers.").

${ }^{102}$ JOEL SLEMROD \& JON BAKIJA, TAXING OURSELVES 160 (4th ed. 2008).
} 
increased complexity and reduced revenue do not preclude making changes to the tax system, ${ }^{103}$ but to justify these additional costs, any change to the current system must provide benefits that offset the costs.

The taxation of mutual fund investors, when compared to the tax treatment of direct portfolio investors or of private investment fund investors, does not meet the standard of vertical equity. In theory, of course, progressive rates apply to all investors, whether they invest through mutual funds, through diversified portfolios, or through private investment funds. However, a flat tax rate of 15 percent applies to long-term capital gains and certain dividends received by most individuals. ${ }^{104}$ True, under current law, individuals in the lowest two tax brackets do not pay taxes on their long-term capital gains, which introduces some level of progressivity in the world of investment income. ${ }^{105}$ But middle-class and wealthy taxpayers will pay taxes at the same rate on their long-term capital gains and qualified dividends. ${ }^{106}$ In general, because of the preferential rate on investment income, the taxation of investments violates vertical equity norms.

In addition to the tax law's failure to apply vertical equity norms to investors generally, the taxation of mutual fund investors fails to meet the standard of vertical equity. Annually, mutual fund investors pay taxes on both the actual income distributed to them or reinvested in the fund and on the forced realization income that their mutual funds produce. ${ }^{107}$ Investors with direct portfolios do not face the specter of forced realization income and, because they decide when to sell securities, can control when (and even if) they will recognize capital gains. ${ }^{108}$ Private investment fund investors, on the other hand, cannot control the timing of the fund's sales of securities. However, private investment funds can allocate the forced realization income to departing partners, meaning that private investment fund investors do not pay taxes on forced realization income. ${ }^{109}$ Because

\footnotetext{
${ }^{103}$ See, e.g., id. at 165 ("[B] efore we dismiss the U.S. system as unnecessarily complex and therefore too costly, we must consider what, if anything, this complexity is buying us.").

${ }^{104}$ I.R.C. $§ 1(\mathrm{~h})(1)(\mathrm{C}),(11)(2006)$.

${ }^{105} \operatorname{Id} . \S 1(\mathrm{~h})(1)(\mathrm{B})$.

${ }^{106}$ Because of the flat rate on investment income, progressive tax rates will only apply to investors' short-term capital gains, interest income, and potentially to certain dividends.

${ }^{107}$ See supra notes 64-69 and accompanying text.

${ }^{108}$ I.R.C. $\$ 1014$ (2006).

${ }^{109}$ See supra notes 69-79 and accompanying text.
} 
mutual fund investors pay taxes on forced realization income while wealthy investors can avoid such income altogether, the tax regime governing mutual funds and their investors violates vertical equity norms, and should be rectified.

In addition to making the taxation of mutual fund investors fairer, rectifying the tax burden on mutual fund investors could reduce disincentives from saving and investing faced by individuals. The imposition of an income tax functions as a "double tax on value that is not immediately consumed." 110 As such, it "encourages current consumption, and thereby discourages the saving of income," even if, absent taxes, people would prefer to save or invest. ${ }^{111}$ Arguably, some portion of Americans' low savings rate should be attributed to the imposition of an income tax. ${ }^{112}$ Although eliminating this distortion of taxpayers' savings and consumption preferences would require a fundamental reform, decreasing the tax hit mutual fund investors face could help to encourage savings and investment.

To encourage middle-class investment and make the tax system more fair, then, the tax law needs to address the issue of forced realization income. And, to some extent, it already has. In 2010, 70 percent of U.S. households reported having an individual retirement account (an "IRA"), an employer-sponsored retirement plan (such as a 401(k) plan), or both. ${ }^{113}$ In 2009 , about 46 percent of IRA assets were invested in mutual funds. ${ }^{114}$ Similarly, in 2008, mutual funds represented about 47 percent of $401(\mathrm{k})$ plan assets. ${ }^{115}$ Moreover, about half of the mutual funds held by U.S. households are held through these tax-advantaged retirement accounts. ${ }^{116}$

As long as an investor holds her mutual fund shares through an IRA or a $401(\mathrm{k})$ retirement plan, she is protected from paying taxes on forced realization income that mutual funds necessarily generate. The

\footnotetext{
${ }^{110}$ Edward J. McCaffery, The Uneasy Case for Capital Taxation, in Taxation, Economic Prosperity, and Distributive Justice 166, 172 (Ellen Frankel Paul, Fred D. Miller, Jr., \& Jeffrey Paul, eds., 2006).

${ }^{111}$ John S. Nolan, The Merit of an Income Tax Versus a Consumption Tax, 12 AM. J. TAX POL'Y 207, 212 (1995).

${ }^{112} I d$.

${ }^{113}$ ICI FACTBOOK , supra note 4, at 102.

${ }^{114} \mathrm{ICI}$-Frequently Asked Questions About Individual Retirement Accounts (IRAs) [hereinafter, ICI, IRAs], http://www.ici.org/faqs/faqs_iras (last visited July 27, 2012).

${ }_{115}$ ICI-Frequently Asked Questions About 401(k) Plans [hereinafter, ICI, 401(k), http://www.ici.org/faqs/faqs_401k (last visited July 9, 2012).

${ }^{116}$ Coates , supra note 10, at 608.
} 
tax law still requires mutual funds held through IRAs and 401(k) accounts to pay dividends of substantially all of their income to investors. These required dividends still include gains on securities the mutual funds had to sell to meet its dividend and redemption requirements. But IRAs and 401(k) plans are tax-deferred retirement plans; investors do not pay taxes on their income or gains from the plans until they withdraw their money. ${ }^{117}$ Instead, they reinvest their dividends in the fund, which maintains the net asset value of their fund.

Still, even with access to IRAs and 401(k) plans, middle-class investors remain on unequal footing with wealthy investors. Holding investments through these tax-deferred retirement accounts still does not provide an investment vehicle equivalent to those available to the wealthy for a number of reasons, both tax-related and not. Although IRAs and 401(k) plans permit a taxpayer to defer the taxation of her investment income, when she withdraws income from the plan, she pays taxes at ordinary, not capital, rates. ${ }^{118}$ The imposition of tax at ordinary rates, irrespective of the underlying character of the mutual fund's gains, can make investments in mutual funds through retirement accounts "unattractive relative even to taxable investments in mutual funds."119

Retirement account investors could avoid this taxation if they never withdrew money from their retirement accounts. In fact, direct investors in portfolio securities can entirely avoid paying income taxes on their gains by holding their securities until death. ${ }^{120}$ In general, though, the owners of tax-advantaged retirement accounts cannot defer their gains until death. Instead, the tax rules governing IRAs and $401(\mathrm{k}) \mathrm{s}$ require investors to take mandatory distributions. ${ }^{121}$ This concomitantly requires them to pay taxes at ordinary rates on those distributions.

In addition to the disadvantageous tax aspects associated with retirement fund distributions, investors face limitations on whether and how much they can contribute to a retirement fund in the first place. 401(k) plans must be established by an employer. ${ }^{122}$ If a taxpayer's

\footnotetext{
117 Id.

118 See Kertz \& Simko, supra note 51, at 103 n.2. Roth IRAs represent an exception to this rule, with no tax imposed on withdrawals. Id.

${ }^{119}$ Coates, supra note 10 , at 608 .

${ }^{120}$ I.R.C. $\S 1014$ (2006).

${ }^{121}$ Id. $\S \S 401(\mathrm{a})(9), 408(\mathrm{a})(6)$ (2006).

122 Treas. Reg. $\$ 1.401(\mathrm{a})-1(\mathrm{~b})(1)(\mathrm{i})$ (as amended in 2007).
} 
employer does not offer a 401(k) plan, an IRA is her only option for tax-deferred investment. In 2012, an individual can contribute $\$ 5,000$ to her IRA, and $\$ 17,000$ to her $401(\mathrm{k})$ retirement account. ${ }^{123}$ To the extent her savings in any given year exceed the amount she can put into her IRA and her 401(k), she must pay taxes on forced realization income, taxes that can be avoided by wealthier investors.

Even where her investments will not exceed the amount that she could contribute to tax-advantaged retirement funds, moreover, the retirement funds may not provide her with the flexibility that she needs. In general, if taxpayer takes a distribution from her 401(k) plan or her IRA before she turns 591/2, she will not only have to pay taxes on the amount distributed, but she will have to pay an additional 10 percent tax on the distributed amount. ${ }^{124}$

Moreover, to the extent that tax-advantaged retirement plans provide net advantages to investors, those advantages do not accrue solely to the middle class. The wealthy also have access to these plans. As such, the availability of these tax-deferred savings vehicles does not bring middle-class investors' options closer to those available to the wealthy.

IRAs and 401(k) accounts also fail to close the gap between investment options available to the wealthy and to the middle-class for at least one significant non-tax reason. The government rightly encourages individuals to save for retirement, but investors often have other savings goals, too. While nearly all mutual fund investors are saving for retirement, nearly half are also saving for emergencies, and a quarter of mutual fund investors are saving for an education. ${ }^{125}$ The wealthy can save for emergencies, education, and other non-retirement objectives without facing taxation on forced realization income; middle-class mutual fund investors generally cannot counteract the tax on forced realization income for non-retirement savings goals.

\section{RESTORING INVESTMENT EQUITY FOR MIDDLE-ClASS INVESTORS}

Paying taxes on forced realization income treats mutual fund investors-many of whom are low- or middle-class-worse than the

\footnotetext{
${ }^{123}$ I.R.S. Notice 2011-90; 2011-2 C.B. 791.

${ }^{124}$ I.R.C. $\$ 72(\mathrm{t})(1)$ (2006). The 10-percent penalty on early withdrawals is subject to certain hardship exceptions. Id. § 72(t)(2).

${ }^{125}$ ICI FACTBOOK, supra note 4 , at 81.
} 
tax law treats investors who can afford other types of investments. Any solution to the problem needs to take into account these investors' relative lack of access to sophisticated financial and tax advice. A solution that imposed cumbersome compliance requirements could be worse than the problem it attempts to fix. As a result, this Article's proposed solution to the problem of forced realization income is simple. Mutual fund shareholders should be permitted to exclude 10 percent of their capital gain dividends from their gross income annually.

Though the solution is simple, explaining the policy choices underlying the solution, as well as some secondary implications of the exclusion, including the allocation of basis and the determination of which shares a shareholder redeems, is more complex. In this Section, the Article will detail the technical problems and solutions associated with the 10-percent exclusion.

Upon implementation, though, these complexities will remain invisible to mutual fund investors. Mutual funds must provide redeeming shareholders with information, including their sale price, adjusted basis, and holding period in the shares they redeemed. ${ }^{126}$ Whether or not Congress implemented this 10-percent exclusion, mutual funds would need to calculate shareholders' bases and provide that information to them. As a result, notwithstanding the intricacies of arriving at the best solution to the problem of forced realization income, once in place, shareholders will generally not face any additional administrative difficulties. ${ }^{127}$

\section{A. A Proportionate Response}

To make mutual fund taxation more equitable, Congress should permit mutual fund shareholders to exclude from their gross income 10 percent of the capital gain dividends they receive each year from mutual funds, provided they reinvest those dividends in the fund. Moreover, to promote vertical equity and to prevent the government

\footnotetext{
${ }^{126}$ I.R.C. $§ 6045$ (b) (2006) (requiring brokers to provide certain information to redeeming shareholders); Treas. Reg. $§ 1.6045-1$ (b) Ex. 1(i) (as amended in 2010) (including mutual funds in definition of "broker"); -1(d)(2)(i) (detailing information a broker must provide shareholders).

${ }^{127}$ The one exception would be shareholders for whom the 10-percent exclusion had phased out. The phaseout will only apply to shareholders at higher income levels, however, who have better access to financial and tax advice.
} 
from losing too much revenue, the exclusion should phase out as a shareholder's income increases.

This exemption will not perfectly solve the problem of forced realization income, of course. How much forced realization income a mutual fund produces depends on the number and value of redemptions in any given year, the securities it chooses to sell, and the amount of built-in gain or loss in those securities, as well as its cash on hand. If mutual funds had to calculate annually the amount of forced realization income they distributed to shareholders, the solution would be administratively infeasible. An administrable solution would be to choose a proxy for the amount of forced realization income a mutual fund shareholder could expect to receive.

No study could quantify exactly how much forced realization income each mutual fund-holding household receives each year. The variables that determine that amount-including the identity and value of the mutual funds held by the household and the quantity of redemptions made by the mutual fund-will differ from household to household. Still, we have some data that we can use to determine a fair exclusion amount.

In 2011, roughly 52.3 million U.S. households owned mutual funds. ${ }^{128}$ The number of mutual fund-owning households has stayed relatively steady over the last decade. ${ }^{129}$ Those 52.3 million households held more than 80 percent of mutual fund assets; taxable household accounts alone held 34 percent of mutual fund assets. ${ }^{130}$

\begin{tabular}{|ll|}
\hline $\begin{array}{l}\text { Capital Gain Distributions to } \\
\text { Taxable Household Accounts } \\
\text { (in billions of dollars) }\end{array}$ \\
\hline 1998 & $\$ 61$ \\
1999 & $\$ 82$ \\
2000 & $\$ 115$ \\
2001 & $\$ 16$ \\
2002 & $\$ 6$ \\
2003 & $\$ 6$ \\
\hline
\end{tabular}

\footnotetext{
${ }^{128}$ ICI FACTBOOK, supra note 4 , at 86.

129 Id.

${ }^{130} \mathrm{Id}$. at 204. Tax-deferred household accounts and tax-exempt fund accounted for another 56 percent of mutual fund, while 11 percent were held by taxable nonhousehold accounts. $I d$.
} 


\begin{tabular}{|ll|}
\hline 2004 & $\$ 21$ \\
2005 & $\$ 45$ \\
2006 & $\$ 80$ \\
2007 & $\$ 135$ \\
2008 & $\$ 30$ \\
2009 & $\$ 4$ \\
2010 & $\$ 18$ \\
2011 & $\$ 30$ \\
& \\
Average & $\$ 46.4$ \\
\hline
\end{tabular}

Table $1^{131}$

The gross amount of capital gain dividends distributed to shareholders has varied wildly from year to year. In 2011, however, mutual funds distributed $\$ 30$ billion of capital gain dividends to taxable household accounts. ${ }^{132}$ The total capital gain dividends from 2011 were slightly lower than the average annual capital gain dividend from 1998 to 2011 of $\$ 46.4$ billion. ${ }^{133}$ Currently there are no data on what portion of mutual funds' capital gain dividends represent forced realization income; moreover, the amount of forced realization income would differ from fund to fund and from year to year. As such, it is currently impossible to determine the precise level of exemption that would perfectly ameliorate the harms of forced realization income. ${ }^{134}$ As a result, an approximation, such as 10 percent of a mutual fund shareholder's capital gain dividends, is the best we can currently do.

Any exclusion amount would represent a loss of revenue to the government. But a 10-percent exclusion would not cost the

\footnotetext{
${ }^{131} I d$. at 207.

${ }^{132} I d$. By way of comparison, in 2009, funds only paid capital gain dividends of $\$ 4$ billion, while in 2007, they paid capital gain dividends of $\$ 135$ billion. Id.

${ }^{133}$ Id. See Table 1.

${ }^{134}$ If the government wanted more precision in its exemption amount, it could determine the average amount of capital gain dividends from mutual funds that represented forced realization income, and set the exemption at that amount, or it could require each mutual fund to determine annually what portion of its capital gain dividends represented forced realization income and to include that amount on its annual statement to shareholders. Both of these solutions, though, seem more administratively intense than necessary; a broad 10 percent exclusion is easy to figure out, easy for mutual funds and shareholders to comply with, and easy for the I.R.S. to administer.
} 
government much comparatively. It would have reduced government revenue in 2011 by not more than $\$ 450$ million. ${ }^{135}$ By way of comparison, the mortgage interest deduction reduced government revenues by an estimated $\$ 98.3$ billion in $2011,{ }^{136}$ while the deduction for charitable contributions cost the government about $\$ 34.5$ billion. $^{137}$ The cost of this 10 percent exclusion would fall more in line with the deduction of interest on student loans, which cost the government an estimated $\$ 500$ million in 2011 . $^{138}$

In practice, moreover, the exclusion would cost the government less than the estimated $\$ 450$ million. Tax-exempt retirement funds hold approximately 40 percent of mutual fund assets. Because taxpayers who hold mutual funds through these funds do not owe taxes on capital gain dividends under current law, exempting 10 percent of capital gain dividends from tax will not further reduce government revenue. ${ }^{139}$ In addition, under current law, households in the bottom two tax brackets pay no taxes on their capital gains. ${ }^{140}$ As a result, the exemption will not decrease the taxes they pay. Moreover, the exemption will phase out for higher income shareholders. ${ }^{141}$ As a result, the full exemption will not be available to all households that would otherwise qualify, and these high-income mutual fund shareholders will pay taxes on more than 90 percent of their capital gain dividends. An exclusion of 10 percent of a taxpayer's capital gain dividends would thus largely ameliorate the problems created by forced realization income without undue cost to the government.

\footnotetext{
${ }^{135} \$ 30$ billion $\times 10 \%$ (exempt amount) $\times 15 \%$ (tax rate on long-term capital gains) = $\$ 450$ million. This number does not take into account changes in behavior that the exclusion would cause. Dynamic scoring, however, requires making assumptions that are beyond the scope of this Article. See, e.g., Heather Bennett, Crippen on Dynamic Scoring: Fish or Cut Bait, 95 TAX NOTES 1714, 1714 (2002) (“[T]he CBO can't implement dynamic scoring and retain any sort of credibility, Crippen charged, because dynamic scoring requires that his office factor in assumptions about future economic growth and future fiscal policy.").

${ }^{136}$ Joint Committee on Taxation, Estimates of Federal Tax Expenditures For Fiscal Years 2010-2014, at 39 (2010).

${ }^{137} I d$. at 47.

${ }^{138} I d$. at 44 .

${ }^{139}$ In 2009, IRAs held about 17 percent of mutual fund assets, ICI, IRAs, supra note 114, while 401(k) plans held an additional 33 percent of mutual fund assets at the end of 2008. ICI, 401(k), supra note 115.

${ }^{140}$ I.R.C. $\S 1(\mathrm{~h})(1)(\mathrm{B})$.

${ }^{141}$ See infra Section V.D.
} 
1. Historical Precedents

Permitting taxpayers to exclude from their income a portion of the dividends they receive is not a novel approach. For 32 years, corporate shareholders could exclude a set amount of dividends from their gross income. Under the Internal Revenue Code of 1954, individuals could exclude up to $\$ 50$ of dividends received from domestic corporations from their gross income. ${ }^{142}$ Congress intended for this exclusion to "afford[] complete relief from the double tax on small amounts of dividend income." ${ }^{, 43}$ Though Congress did not index the exemption to inflation, in 1980, the amount of dividends excludable from gross income temporarily increased to $\$ 200$, or $\$ 400$ for married taxpayers filing jointly. ${ }^{144}$ In 1981 , it returned to its pre1980 levels, and it was ultimately repealed by the Tax Reform Act of $19866^{145}$

Still, the former dividend exclusion differs from the one proposed here in significant ways. The amounts shareholders exclude differs, of course. Moreover, the former dividend exclusion applied to substantially all dividends from domestic corporations, ${ }^{146}$ while this proposal would apply solely to capital gain dividends paid by mutual funds. The former exclusion applied irrespective of a shareholder's income, while this proposal would phase out above an income threshold.

These differences arise because the purpose underlying the exclusion of capital gain dividends proposed here differs from Congress's purpose in permitting taxpayers to exclude a set amount of dividends from income, of course. Where Congress used the broad dividend exclusion to provide partial integration between the corporate and individual income tax regimes, this proposed exclusion would function instead to ameliorate the taxes on forced realization income faced by mutual fund shareholders that do not apply to other investments. Though the two dividend exclusions differ in motivation and in implementation, though, the former exclusion of dividends

\footnotetext{
${ }^{142}$ Internal Revenue Code of 1954, § 116(a), 68A Stat. 3 (1954).

${ }^{143}$ H.R. Rep. No. 83-1622, at 6 (1954).

${ }^{144}$ JT. COMM. TAX., GENERAL EXPLANATION OF THE CRUDE OIL WindFALl PROFIT TAX ACT OF 1980, at 122 (1980).

${ }^{145}$ Jane G. Gravelle, The Taxation of Dividend Income: An Overview and Economic Analysis of the Issues (2008).

${ }^{146}$ Internal Revenue Code of 1954, § 116(a), 68A Stat. 3 (1954).
} 
demonstrates that the tax law is capable of implementing and administering an exclusion regime.

2. Excluding Capital Gain Dividends

More recently, an exclusion of capital gain dividends has been proposed in Congress to make mutual fund taxation more equitable. In the 110th Congress, Representative Jim Saxton sponsored a bill that would allow mutual fund shareholders to defer taxation on up to $\$ 5,000$ (or $\$ 10,000$ in the case of a joint return) of capital gain dividends annually. ${ }^{147}$ This deferral would be available to shareholders who automatically reinvested their dividends and would be indexed for inflation. ${ }^{148}$

Rep. Saxton proposed his $\$ 5,000$ deferral to make mutual fund taxation more equitable, especially for low- and middle-income Americans. The proposed bill is problematic, however: by permitting shareholders to defer paying taxes on up to $\$ 10,000$ of reinvested capital gain dividends, it would effectively eliminate the taxation of mutual fund capital gains until shareholders redeemed their shares or stopped reinvesting their dividends. With such a high exclusion, approximately 85 percent of mutual fund shareholders would be able to defer the entire amount of capital gain dividends they received from their mutual funds annually. ${ }^{149}$ Such a full exclusion would put mutual fund shareholders in a significantly better position than investors in pass-through entities.

Why such a generous exclusion in the proposed bill? According to the report of the Joint Economic Committee (chaired by Rep. Saxton), there appear to have been two reasons. First, the Joint Economic Committee worried about shareholders' lack of liquidity. Paying taxes on reinvested capital gain dividends could force shareholders to sell shares, even when they did not want to, to pay their tax bill. ${ }^{150}$ Second, the Committee argued that taxing capital gain dividends violated the horizontal equity between mutual fund

\footnotetext{
${ }^{147}$ H.R. 397, 110th Cong. $\$ 1$ (2007).

${ }^{148} I d$.

${ }^{149}$ See Coates, supra note 10, at 616; JoInt ECON. COMMITTEE, THE TAXATION OF Mutual Fund InVESTORS: PERFORMANCE, SAVING AND INVESTMENT 18-19 (2001).

${ }^{150} I d$. at 4 ("Unfortunately, the current tax law treatment of capital gain realizations also can force shareholders of mutual funds to pay capital gain taxes on their mutual fund holdings even when shareholders choose not to sell shares.”).
} 
shareholders and similarly-situated investors who owned stock directly. ${ }^{151}$

Neither of these concerns compels such a high exclusion amount, however. Mutual fund shareholders can receive their dividends in cash, rather than reinvesting the dividends; in fact, mutual funds cannot require shareholders to reinvest their dividends. ${ }^{152}$ If a shareholder believed she could not otherwise afford her tax bill, she could elect to receive all or a portion of her dividend in cash.

Moreover, according to the report, mutual fund shareholders and direct shareholders are not similarly-situated. Although the mutual fund taxation rules attempt to create rough parity between mutual fund shareholders and direct investors, significant differences exist between mutual fund and direct investors. For example, low- and middleincome households invest in mutual funds precisely because "they usually cannot afford the relatively large amounts of capital necessary to build their own diversified portfolio of stocks." ${ }^{153}$ If a mutual fund shareholder cannot afford the diversified portfolio that a direct investor holds, the two investors are not similarly situated and addressing horizontal equity between direct and mutual fund investors does not help to determine the proper tax treatment of mutual fund shareholders.

Such a high exclusion amount would effectively transform mutual funds from quasi-pass-through entities into tax shelters. Under Rep. Saxton's proposal-like under this proposal-the ability of mutual fund shareholders to exclude a portion of their dividends would not affect the fund's ability to take a deduction for dividends paid. As such, the mutual fund would not pay taxes on the gains it distributed to shareholders. But shareholders who reinvested their dividends in the paying fund would not pay taxes on their share of the fund's capital gains in the year earned either. The capital gain dividends would, instead, increase the value of the shareholders' investment in the fund. Eventually, if a shareholder redeemed her shares, she would pay taxes on the dividends in the form of additional gain on her shares. But if, instead, she held the shares until death, she could bequeath them to her

${ }^{151} I d$. at 5 ("This treatment violates the economic principle of horizontal equity.").

${ }^{152}$ In order for a mutual fund - or any other corporation - to treat a distribution of its own stock as a dividend, shareholders must have the right to elect to receive the distribution either in the form of cash (or other property) or the payor's stock. I.R.C. $\S 305(b)(1)$.

${ }^{153} \mathrm{Id}$. 
heirs, untaxed, and her heirs could step up their basis in the shares. ${ }^{154}$ Effectively, up to $\$ 10,000$ of gains per year could remain permanently untaxed. ${ }^{155}$

This exemption would almost certainly ameliorate the vertical equity problem, of course. It seems virtually impossible that a middleclass mutual fund investor would receive dividends that included more than $\$ 10,000$ of forced realization income in a year. But the ability to shelter a significant amount of income would materially impact the federal government's revenue. Moreover, it would have significant distortionary effects. Wealthy investors would have incentive to shift some significant portion of their investment strategy from private investment funds to mutual funds, because mutual funds would allow them to shelter $\$ 10,000$ of income per year. ${ }^{156}$ And mutual funds would face pressure to shift their investment strategies in a way that maximized their net long-term capital gains at the expense of other types of income. ${ }^{157}$ To maximize its long-term capital gains, a mutual fund would need to hold its securities for longer than one year, ${ }^{158}$ but investors would demand that it sell its appreciated securities as soon as it had held them long enough, irrespective of what the fund would have done absent tax-induced distortions.

While vertical equity concerns argue in favor of ameliorating the effects of forced realization income on middle-class and poor mutual fund shareholders, they do not support an exclusion so large that it risks transforming mutual funds into tax shelters. They do not support creating significant distortions in the investment decisionmaking of mutual funds. And they do not support creating significant distortions in the investment decisions of investors. A more modest

\footnotetext{
${ }^{154}$ I.R.C. $\S 1014($ a) (2006).

${ }^{155}$ See Samuel D. Brunson, Taxing Investors on a Mark-to-Market Basis, 43 LoY. L.A. L. REV. 507, 514 n.19 (2010) ("In fact, under I.R.C. § 1014(a)(1), if she holds an appreciated security until her death, her heirs will inherit the appreciated security with a tax basis equal to its fair market value as of the date of her death. Any appreciation in the value of the security as of that date remains permanently untaxed.").

${ }^{156}$ Specifically, it would make sense for wealthy investors to shift enough of their investments from private funds to mutual funds so that they would receive $\$ 10,000$ of capital gain dividends a year.

${ }^{157}$ A mutual fund's capital gain dividend is the amount it designates as such, but cannot exceed its "net capital gain." I.R.C. § 852(b)(3)(C) (2006); Treas. Reg. § 1.852-4(c)(1) (as amended in 1984). A mutual fund's net capital gain is its longterm capital gain reduced by its short-term capital loss. Id. §1222(11).

${ }^{158}$ Id. § 1222(3).
} 
exclusion, such as the one proposed here, would ameliorate the inequitable effects of forced realization income on the tax bills of middle-class investors while, at the same time, not providing such a significant tax benefit that it will change the investment decisions of wealthy investors or mutual funds themselves.

\section{Capital Gain Dividends}

This proposal would only permit mutual fund shareholders to exclude a portion of their capital gain dividends. But mutual funds' income does not consist solely of long-term capital gains. A mutual fund can also receive dividends on the corporate stock they hold and interest on bonds. To maintain its beneficial tax status, it must distribute to shareholders not only substantially all of its net capital gain, but substantially all of its dividend and interest income, too. ${ }^{159}$

No part of a mutual fund's forced realization income consists of dividend or interest income, however. The amount of dividends and interest a mutual fund receives not only falls outside the fund's control, it has no connection with shareholders' redemptions. Dividends and interest represent real accessions to wealth for the mutual fund. Upon receiving a dividend distribution or interest payment, the mutual fund's net asset value increases and, with it, the value of shareholders' shares. Moreover, a shareholder's paying taxes currently on her pro rata share of the fund's income does not violate vertical equity considerations. An investor with direct portfolio holdings also pays taxes upon receipt of interest and dividends. Although she can determine when to realize appreciation by selling her securities, she does not control when or if she will receive dividends, ${ }^{160}$ and market demands determine the amount of interest paid on corporate bonds. ${ }^{161}$ Likewise, private investment funds cannot "stuff" interest and

\footnotetext{
${ }^{159}$ I.R.C. § 851(b)(2)(A) (2006).

${ }^{160}$ Dividends are paid at a corporate board's discretion; shareholders cannot require that the board declare and pay dividends. See, e.g., Lynn A. Stout, The Shareholder as Ulysses: Some Empirical Evidence on Why Investors in Public Corporations Tolerate Board Governance, 152 U. PA. L. REV. 667, 676 (2003) ("Shareholders cannot pay themselves dividends; if a dividend is declared at all, it must be declared by the board. If the board refuses to declare a dividend, in the typical public firm there is little the shareholders can do about it.").

${ }^{161}$ See, e.g., Michael S. Knoll, Compaq Redux: Implicit Taxes and the Question of Pre-Tax Profit, 26 VA. TAX REV. 821833 (2007) ("Thus, we can expect competition among investors and issuers to drive down the interest rate on municipal bonds and drive up the interest rate on corporate bonds.").
} 
dividend income to departing investors. All investors pay taxes on their interest and dividends, and mutual fund investors should not be different in this regard.

Moreover, determining what portion of their mutual fund dividends represent capital gain dividends should not create any administrative burden for mutual fund shareholders. Every year, mutual funds must provide an I.R.S. Form 1099-DIV to their shareholders. ${ }^{162}$ In Box 2a, of the Form 1099-DIV, a mutual fund designates the amount of capital gain dividend received by the shareholder. ${ }^{163}$ As such, mutual fund shareholders already have the information they need to determine the amount of capital gain dividends they receive each year. Limiting the exclusion to capital gain dividends should not present them with any material administrative difficulty.

\section{Reinvestment}

This proposed exclusion would not affect the taxation of mutual funds themselves. Under this dividend-exclusion regime, the tax law would continue to treat mutual funds as quasi-pass-through entities, and mutual funds would still need to distribute substantially all of their income, including phantom gains generated when redeeming departing shareholders. Mutual funds would continue to deduct from their taxable incomes their dividends paid, and shareholders would continue to look through the dividends to characterize their income. The only change to the subpart $\mathrm{M}$ regime would be to the taxation of mutual fund shareholders: such shareholders would not include in income, and therefore not pay taxes on, all of her mutual fund dividends.

Still, the forced realization income problems do not require an unbounded exclusion; as such, the proposal limits the amount of the exclusion $^{164}$ and the particular type of dividend to be excluded. ${ }^{165}$ In addition to those exclusions, a shareholder would only be permitted to exclude her capital gain dividends if she reinvested those dividends in the fund through a dividend reinvestment plan. Although distributions

\footnotetext{
162 Treas. Reg. § 1.6042-3(a)(3) (as amended in 2000).

${ }^{163}$ I.R.S. Form 1099-DIV; see also I.R.C. § 852(b)(3)(C) (2006) (permitting mutual funds to designate the amount of their capital gain dividend in a written statement to shareholders).

${ }^{164}$ See supra notes $147-158$ and accompanying text.

165 See supra notes 159-163 and accompanying text.
} 
of forced realization income do not necessarily represent economic gain to mutual fund shareholders, ${ }^{166}$ neither do ordinary corporate dividends. Instead, receiving a dividend unlocks the appreciation that the corporation-mutual fund or not-has amassed. Rather than taxing this appreciation as it occurs, though, shareholders of ordinary corporations defer their tax liability until they receive some sort of "tangible benefit."167

When a mutual fund shareholder receives a dividend and does not reinvest it in the fund, she has complete control over the money. She can use it to purchase whatever property she likes. By keeping the dividend, she has received a tangible benefit of a type that generally triggers taxation. Where a shareholder reinvests her dividend subject to a dividend reinvestment plan, on the other hand, she neither receives a tangible benefit from the dividend nor improves her economic situation. Under a dividend reinvestment plan, shareholders can elect whether to take their dividends in cash or in additional stock of the mutual fund paying the dividend. ${ }^{168}$ The mutual fund shareholder who elects to participate in the dividend reinvestment plan includes the value of the additional stock in income as if it were cash, while the mutual fund can take a dividends paid deduction for the same amount, even though the additional shares do not represent an expense to the mutual fund. ${ }^{169}$ Dividend reinvestment plans create no non-tax economic consequences for mutual fund shareholders. The only difference from the shareholder's point of view is that the she will own more shares of the fund, albeit with the same value as her shares had before.

Because dividends received in the form of shares have no economic consequence to shareholders and do not unlock any value, limiting the exclusion to dividends reinvested in the paying mutual

\footnotetext{
${ }^{166}$ See supra notes 67-69 and accompanying text.

167 Jeffrey L. Kwall, When Should Asset Appreciation Be Taxed? The Case for a Disposition Standard of Realization, 86 IND. L.J. 77, 80 (2011) ("By conditioning realization on the contemporaneous receipt of a tangible benefit, the courts treated asset appreciation in the same manner as other forms of income . .., which normally occur when a person receives money or property.").

${ }^{168}$ DEP'T OF TREASURY, REPORT ON INTEGRATION OF THE INDIVIDUAL AND CORPORATE TAX SYSTEMS: TAXING BusineSs INCOME ONCE 87 (1992) ("We contemplate that this would be permitted through an elective dividend reinvestment plan (DRIP). DRIPs may be adopted by corporations under current law; such plans commonly are used by mutual funds and utilities.").

${ }^{169}$ Treas. Reg. $§ 1.605-2(b)$ Example 2 (as amended in 1973).
} 
fund subject to a dividend reinvestment plan is not unfair to investors who receive their dividend payments in cash. The receipt of cash provides a separate basis for taxation, and differs materially from the reinvested dividends.

Relatedly, the rules should be written in such a way that a mutual fund shareholder cannot reinvest only her capital gain dividends, while taking the rest of her mutual fund dividends in cash. Rather, to the extent that her dividend reinvestment plan applies only to a portion of her dividend, the proportion of the reinvested dividend treated as a capital gain dividend to the full amount reinvested should be the same as the proportion of entire capital gain dividend to the full mutual fund dividend.

That is, assume that Mutual Fund X pays a \$100 dividend, \$20 of which it designates as a capital gain dividend. Jane, a shareholder, reinvests $\$ 20$ subject to the fund's dividend reinvestment plan and takes the other $\$ 80$ in cash. Under these proposed rules, she could not claim that the reinvested $\$ 20$ was entirely a capital gain dividend, and exclude $\$ 2$ from income. Instead, because the capital gain dividend represents 20 percent of the full dividend, only 20 percent of the reinvested amount (or \$4) can be treated as a capital gain dividend. As a result, Jane could not exclude more than $\$ 0.40$ from income. ${ }^{170}$

\section{B. Other Reform Options}

Congress has other options that could also address the inequities faced by mutual fund shareholders. It could, for example, replace the current income tax with a consumption tax, which would entirely eliminate the taxation of capital gains. ${ }^{171}$ If gains did not constitute taxable income, mutual fund investors would be indifferent, for tax purposes at least, to the fund's selling securities to redeem shareholders. ${ }^{172}$

\footnotetext{
170 \$2:\$100::\$0.40:\$20.

${ }^{171}$ Coates, supra note 10, at 614 ("The simplest, most general improvement for taxation of mutual funds would be to eliminate taxes on capital gains altogether.”).

${ }^{172}$ While there are arguments in favor of shifting from an income tax to a consumption tax, mutual fund investors' forced realization income seems insufficient to justify such a seismic shift. See, e.g., Michael J. Graetz, Implementing a Progressive Consumption Tax, 92 HARV. L. REV. 1575, 1661 (1979) (“[T]he practical problems of implementing a graduated tax on consumption are indeed great-far greater than has been previously suggested by its recent proponents. Given these practical difficulties, proponents of such a tax should be required to demonstrate that its claimed advantages in terms of equity and economic efficiency are real and cannot be achieved in a simpler fashion."). As such, while
} 
As one solution, Congress could include mutual funds among true pass-through entities. As true pass-through entities, mutual funds could "stuff" gains to departing shareholders. ${ }^{173}$ Moving mutual funds from their current quasi-pass-through status to a true pass-through status would not represent a fundamental change of the tax law; rather, it addresses the problem of mutual fund forced realization income by altering the taxation of mutual funds specifically. However, it would represent a fundamental change in the tax treatment of mutual funds.

However, the additional complexity and costs mutual funds and their shareholders would incur as a result of such a fundamental change would likely counterbalance the benefits of eliminating forced realization income. ${ }^{174}$ Pass-through tax treatment originally aimed to provide taxpayers with flexibility. ${ }^{175}$ With that flexibility, however, came abuses as taxpayers began shifting income and other tax attributes in ways Congress had not anticipated. ${ }^{176}$ In response, the tax rules governing pass-through entities have become more and more complex, technical, and costly to comply with. ${ }^{177}$ For wealthy investors, the advantages of true pass-through status are significant enough that it makes economic sense for them to deal with the complexity and cost of a true pass-through regime; for the average mutual fund investor, however, "it is not clear that the benefits of reduced capital gains taxes would be worth the annual additional tax compliance and record-keeping costs that partnership tax would create." 178

Alternatively, Congress could reduce or eliminate mutual funds' distribution requirement. While this would significantly change

fundamentally altering the federal tax regime would solve the inequities faced by mutual fund investors, arguing in favor of a consumption tax is beyond the scope of this Article.

${ }^{173}$ See supra notes 69-79 and accompanying text.

${ }^{174}$ Coates, supra note 10, at 614.

${ }^{175}$ Lawrence Lokken, Imagining a Future Without Subchapter K, 4 FLA. TAX REV. 249, 250 ("The original conception of subchapter K [was] flexibility with some limitations.").

${ }^{176} I d$.

${ }^{177}$ Andrea Monroe, What's in a Name: Can the Partnership Anti-Abuse Rule Really Stop Partnership Tax Abuse?, 60 CASE W. RES. L. REV. 401, 402-03 (2010) ("Taken together, these problems have triggered another of subchapter K's afflictionscomplexity.”); see also Am. Law Inst., Federal Income Tax Project Subchapter K, at 7 (1984) ("The pure pass-through model can only be achieved in practice at an intolerable cost in complexity.").

${ }^{178}$ Coates, supra note 10, at 614 . 
the current tax qualification of mutual funds, it would not constitute a fundamental change in their nature. If mutual funds did not have to distribute substantially all of their income, they could avoid distributing taxable forced realization income to their shareholders. Because mutual funds are corporations, rather than true pass-through entities, mutual fund shareholders do not pay taxes on income when the mutual fund earns it. Rather, they pay taxes when the mutual fund distributes its income as dividends. ${ }^{179}$ Mutual funds achieve their quasi-pass-through status by virtue of two things: first, mutual funds can designate a portion of their dividends as "capital gain dividends." ${ }^{180}$ Shareholders pay taxes at long-term capital gain rates on the capital gain dividend portion of the fund's dividend, ${ }^{181}$ which essentially permits shareholders to look through the mutual fund to determine the character of their income.

Second, qualified mutual funds can deduct the dividends they pay from their taxable income. ${ }^{182}$ This deduction for dividends paid eliminates the double taxation mutual fund shareholders would otherwise face. ${ }^{183}$ To qualify for the deduction, though, a mutual fund must distribute substantially all of its income every year. ${ }^{184}$ But for the distribution requirement, a mutual fund would not need to distribute its forced realization income from selling securities to fund redemptions. Eliminating the distribution requirement would allow mutual funds to distribute only real economic income to shareholders.

This solution, too, has problems, however. As a taxable entity, a mutual fund would pay taxes on any income that it did not distribute to shareholders. This is worse than either a direct portfolio investment or an investment in a private investment fund. Direct portfolio investments cannot create forced realization income, while private investments funds do not pay taxes and can allocate phantom gains in such a way that they do not affect the remaining partners or the fund's net asset value.

Moreover, if mutual funds had no distribution requirement, wealthy individuals could use them as tax shelters. Under current law, the corporate tax rate and top individual marginal rate are the same,

\footnotetext{
179 Treas. Reg. $\$ 1.852-4(a)$, (b) (as amended in 1984).

${ }^{180}$ I.R.C. $\$ 852(b)(3)(C)(i)$ (2006).

${ }^{181}$ Id. $\S 852(\mathrm{~b})(3)(\mathrm{B})$.

${ }^{182}$ Id. $\$ 852(\mathrm{~b})(2)(\mathrm{E})$.

${ }^{183}$ See supra notes 39-41 and accompanying text.

${ }^{184}$ See supra notes 49-50 and accompanying text.
} 
but, unless Congress extends the Bush tax cuts, the top two individual marginal rates will rise to 36 percent and 39.6 percent in $2013 .{ }^{185}$ At the same time, corporate tax rates appear likely to fall. ${ }^{186}$ If corporate rates fall significantly below individual rates, there may be tax advantages in leaving as much money as possible — undistributed—in closely-held corporations, including in mutual funds. ${ }^{187}$ And, in fact, if mutual funds continued to qualify for the deduction for dividends received, mutual funds would be even more attractive than ordinary corporations for sheltering income.

Although these other options could also improve the fairness of mutual fund investment, the 10-percent exclusion is a better option. The problem of forced realization income, though significant, clearly does not by itself warrant fundamentally changing federal taxes from income to consumption taxes. Moreover, fundamental alteration of the mutual fund regime could have unintended consequences that make mutual funds less appealing to middle-class taxpayers (or more appealing to wealthy taxpayers who want to avoid taxation).

\section{Calculating Basis}

Because taxable income includes gains from the sale of property, the tax law needs to provide a way for taxpayers to figure out the amount of their gain on which they should pay taxes. Basis plays an essential role in this calculation. When a taxpayer acquires property, that property has a basis. In general, the basis of property is the cost of that property to its owner, ${ }^{188}$ with certain adjustments made to take into account "deductions ... [that] effectively allowing taxpayers to receive money tax free." 189

\footnotetext{
${ }^{185}$ Kirk J. Stark, The Federal Role in State Tax Reform, 30 VA. TAX REV. 407, 427 (2010).

${ }^{186}$ Republic Representative Paul Ryan's 2012 proposed budget resolution would, among other things, reduce the top corporate tax rate to 25 percent. Michael Beller, Obama Calls GOP Budget "Laughable", 135 TAX NOTES 146, 146 (2012). At the same time, President Obama's corporate tax reform framework proposed dropping the corporate rate to 28 percent. Meg Shreve, et al., Obama Offers Corporate Tax Plan Lowering Rate to 28 Percent, 134 TAX NOTES 1045, 1045 (2012).

${ }^{187}$ Martin A. Sullivan, Will Rate Changes Transform C Corps Into Tax Shelters?, 134 TAX NOTES 1590, 1590 (2012).

188 I.R.C. $\$ 1012$ (a) (2006).

${ }^{189}$ Adam Chodorow, Tracing Basis Through Virtual Spaces, 95 CORNELL L. REV. 283, 293 (2010).
} 
An income tax should only tax income once to any one shareholder. ${ }^{190}$ Basis functions as a placeholder for previously-taxed income to avoid its double taxation. ${ }^{191}$ When a taxpayer sells property, she calculates the amount of gain on which she pays taxes by subtracting her basis in the property from the amount she receives in exchange for the property. ${ }^{192}$ The basis, excluded from her gross income, represents the previously-taxed money that she used to acquire the asset.

Assume, for example, that Miles purchased one share of a mutual fund for $\$ 10$. He has presumably already paid taxes on that $\$ 10 .{ }^{193}$ A year later, he sells his share for $\$ 15$. Without some system of basis recovery, he could potentially pay taxes on the full $\$ 15$. The sale does not represent an accession to $\$ 15$ of wealth, however; his economic situation has only improved by $\$ 5$ over the course of the year. Moreover, he only has $\$ 5$ on which he did not previously pay taxes. But, because he has a basis of $\$ 10$, in fact he will only pay taxes on the $\$ 5$ of gain, because he will subtract her basis from the amount realized.

Under this proposal, however, a taxpayer may receive some untaxed mutual fund shares each year. In general, when mutual fund shareholders participate in a dividend reinvestment plan, their basis in their mutual fund shares should increase. Because mutual fund shareholders pay taxes on these reinvested dividends, they need the placeholder of basis so that, when they redeem their shares, they avoid paying taxes on the same income twice.

\footnotetext{
${ }^{190}$ See id. at 292 ("One of the key tenets of any income tax is the notion that income should be taxed once, and only once, in the hands of the same taxpayer.").

${ }^{191}$ See id. ("The rules regarding basis and basis recovery found throughout the Code and regulations are designed to allow taxpayers to track their previously taxed income....").

${ }^{192}$ I.R.C. § 1001(a) (2006). This amount realized includes not only money, but also the fair market value of property and of services she receives in exchange for the property. Id. § 1001(b) (amount realized includes "any money received plus the fair market value of the property (other than money) received"); Int'l Freighting Corp. v. Comm'r, 135 F.2d 310, 313 (2d Cir. 1943) ("Literally, where there is a disposition of stock for services, no 'property' or 'money' is received by the person who thus disposes of the stock.").

${ }^{193}$ This presumption is not true in every case; if Miles received the $\$ 10$ as a gift or bequest, for example, he was not required to include it in his gross income. I.R.C. § 102(a) (2006). But in general, the money taxpayers have was taxed when received. See id. §62.
} 
The exemption raises three significant issues with respect to basis. First, a taxpayer must determine how to allocate the excluded dividends among the mutual funds she owns. Second, she must figure out how to determine her basis in the excluded dividends. And third, when she redeems her shares, she may need to determine which shares of her mutual fund she is redeeming.

1. Allocating the Excluded Dividends

The issue of how to allocate excluded dividends does not matter to a shareholder who either only owns shares of one mutual fund. If the shareholder only owns shares of one mutual fund then all of her excluded dividends will be from that mutual fund. If, however, she owns more than one mutual fund, she will need to determine which dividends she received tax-free.

Congress could choose from at least three methods to determine which capital gain dividends a shareholder should exclude from her income. The tax law could, for example, permit shareholders to elect which of their capital gain dividends they will exempt. Alternatively, the law could designate that the earliest capital gain dividends soaked up the exemption. Or it could require the mutual fund shareholder to divide the exemption pro rata among the capital gain dividends she received during the year.

While any of these three methods would work, dividing the exemption pro rata among the dividends is the best solution. Elective taxation is, at best, problematic. When confronted with a tax election, a taxpayer must spend time evaluating her options, must determine how to make the election, and must actually fulfill the steps to make the election. ${ }^{194}$ The steps necessary to make an election increase the administrative burden on the taxpayer (and, for that matter, on the I.R.S., which must process and police the elections). ${ }^{195}$ In addition to the administrative burden, a taxpayer must either spend time evaluating the consequences of the election herself, or pay somebody else to evaluate it on her behalf. ${ }^{196}$ The costs of tax planning and tax

\footnotetext{
${ }^{194}$ See Heather M. Field, Choosing Tax: Explicit Elections as an Element of Design in the Federal Income Tax System, 47 HARV. J. ON LEGIS. 21, $27-28$ (2010).

${ }^{195}$ Id. at 29 ("This complexity for taxpayers is often mirrored by the administrative burden placed on the IRS.").

${ }^{196}$ Id. at 30 .
} 
advice constitute dead-weight loss. ${ }^{197}$ Moreover, because mutual fund shares are often held by unsophisticated individuals, the administrative costs of making the election would presumably be steeper and more difficult to navigate than elections aimed at sophisticated taxpayers.

In addition to the efficiency costs of electivity, because taxpayers will generally elect tax treatment that reduces their overall tax liability, any tax election will reduce government revenue. ${ }^{198}$ In the case of mutual funds, allowing shareholders to choose which capital gain dividends they will exclude from their income raises real concerns about government revenue. Presumably, if they can choose which mutual fund dividends to exclude from their income, shareholders will elect those shares which they do not plan on selling. Because of the realization requirement of the tax law, as long as they do not sell the shares they received as a dividend, they will continue to defer taxes on their gain. By electing to exclude shares that she did not plan on selling, a shareholder could potentially eliminate taxes on those shares altogether: if she held it until her death, she could eliminate the taxation of the excluded gain.

Providing that the 10 percent exclusion excluded the first capital gain dividends received from mutual funds could also create wasteful distortions. To the extent that a mutual fund wanted a portion of its dividends to be excluded, it would have an incentive to pay dividends as early in the year as possible, whether or not it would have declared dividends at that point. On the other hand, if a mutual fund did not want its dividends excluded, this tax rule would push its dividend toward the end of the year.

While taxes inevitably distort a taxpayer's economic decisionmaking, ${ }^{199}$ applying the exemption to a shareholder's mutual fund dividends in a pro rata manner limits the distortive effect of the proposed regime. Because the tax treatment of capital gain dividends

\footnotetext{
${ }^{197}$ Edward J. McCaffery, The Holy Grail of Tax Simplification, 1990 WIS. L. REV. 1267, 1297 (1990) ("There are, for example, the costs of tax advice and preparation, that can be considered as dead weight losses. The loss becomes especially costly if the provisions do not add to equity or efficiency.").

${ }^{198}$ Field, supra note 194, at 31 ("[A] well-advised rational taxpayer will almost always exercise the election in a way that minimizes its tax liability, at the expense of the fisc.").

${ }^{199}$ See Martin Feldstein, The Welfare Cost of Capital Income Taxation, 86 J. PoL. ECON. S29, S32 (1978) ("Since the individual consumes three distinct 'goods' (i.e., leisure, first-period consumption, and second-period consumption), any tax (other than a lump-sum tax) will impose at least one distorting wedge.").
} 
does not depend on the dividend's timing, mutual funds will choose when to declare and pay their dividends based on economic and business factors. Because shareholders cannot decide which dividends they will exclude from their income, they will not face the administrative burden of determining the most favorable dividends to exclude. True, they will need to calculate how much of each dividend they can exclude from their income, but that calculation is a simple mathematical one, and does not require extraordinary analysis. As a result, mutual fund shareholders should apply the 10 percent exemption pro rata to the capital gain dividends they receive during the course of the year.

\section{Determining Basis}

After a shareholder receives her additional shares and determines which shares are exempt from tax, she must determine her basis in the shares. The problem of assigning basis to shares received as part of a dividend reinvestment plan is not unique to this proposal. Current law already permits mutual fund shareholders to participate in dividend reinvestment plan, receiving distributions of additional shares of the mutual fund rather than cash. ${ }^{200}$ Though shareholders pay taxes on the full value of the shares they receive, that value may differ from the cost of other shares they received pursuant to the dividend reinvestment plan and from the amount they paid for their initial investment. As such, a mutual fund shareholder who elects to participate in a dividend reinvestment plan may own several blocks of mutual fund shares, each potentially with a different basis.

Current law provides for two general methods of determining basis for mutual fund shares purchased in different blocks. Under one method, each block of stock has a separate basis. When a shareholder acquires additional stock in a dividend, she pays taxes on the value of the dividend and takes a basis of the value of the stock received. ${ }^{201}$ Alternatively, a mutual fund shareholder may elect to use the "average basis method" to determine her basis in her mutual fund shares. ${ }^{202}$ Under the average basis method, a mutual fund shareholder looks at all of her shares of the same mutual fund that she has acquired pursuant to a dividend reinvestment plan. ${ }^{203}$ She then calculates the basis of each

\footnotetext{
${ }^{200}$ See supra notes 65-68 and accompanying text.

${ }^{201}$ See I.R.C. $\$ 6045(\mathrm{~g})(2)(\mathrm{B})(\mathrm{i})(\mathrm{I})(2006)$.

${ }^{202} I d . \S 6045(\mathrm{~g})(2)(\mathrm{B})(\mathrm{i})(\mathrm{II})$.

203 Treas. Reg. $\S 1.1012-1(\mathrm{e})(7)(\mathrm{i})$ (as amended in 2010).
} 
share of stock by adding the bases of all of her shares and dividing by the number of shares. ${ }^{204}$

The regulations illustrate this rule using a mutual fund shareholder who, pursuant to a dividend reinvestment plan, periodically receives additional shares of the L Company, a mutual fund. On January 8, 2010, he receives a \$200 dividend, paid in the form of 25 shares of L Company. On February 8, 2010, he receives of $\$ 200$ dividend paid as 24 shares. On March 8, he receives a \$200 dividend paid in 20 shares, and on April 8, he receives a \$200 dividend paid in 20 shares. $^{205}$ As a result of his dividend reinvestment plan, the shareholder has 89 shares of L Company. ${ }^{206}$ His aggregate basis in all of the shares is $\$ 800 .^{207}$ Thus, using the average basis method, he has a basis of $\$ 8.99$ in each share of L Company. ${ }^{208}$

Under current law a mutual fund shareholder determines her basis in accordance with her broker's default method. ${ }^{209}$ If her broker determines basis for each block of shares separately and she does not want to use that method, she can elect to use the average basis method instead. ${ }^{210}$ Providing two methods for calculating basis unnecessarily increases complexity, though. Instead, the law should require shareholders to use the average basis method. Requiring all mutual fund shareholders to calculate their basis using a single method will reduce the administrative burden for taxpayers and for the I.R.S. Moreover, using the average basis method simplifies shareholders' calculation of gain when they redeem their shares. ${ }^{211}$ At the bare minimum, the average basis method should be the default, and taxpayers who would rather use block accounting should be required to affirmatively make an election to do so.

\section{Determining Gain or Loss}

When a mutual fund shareholder wants to convert her investment to cash, she can do so in one of two principal ways. If she owns shares of a closed-end mutual fund, she sells them to another

\footnotetext{
${ }^{204} I d$.

${ }^{205} I d . \S 1.1012-1(\mathrm{e})(7)(\mathrm{vi})$ Ex. 2.

${ }^{206} 25+24+20+20=89$.

${ }^{207} \$ 200+\$ 200+\$ 200+\$ 200=\$ 800$.

${ }^{208}$ Treas. Reg. § 1.1012-1(e)(7)(vi) Ex. 2.

${ }^{209}$ I.R.C. $\S 6045(\mathrm{~g})(2)(\mathrm{B})(\mathrm{i})(\mathrm{II})$.

${ }^{210} \mathrm{Id}$.

${ }^{211}$ See infra Section V.E.
} 
investor on the open market. ${ }^{212}$ She will realize gain or loss on the sale by subtracting her basis in the shares from the amount she realizes on the sale. ${ }^{213}$ By contrast, if she owns an open-ended mutual fund-by far the most common type of mutual fund ${ }^{214}$ - she does not sell her shares on the open market. Instead, the fund stands ready to redeem her shares at their net asset value. ${ }^{215}$ Though an open-end mutual fund's redemption of shares differs from the sale of a closed-end fund's shares on a securities market, the tax law nonetheless treats a corporate redemption as a sale of the stock. ${ }^{216}$ As with closed-end funds, a shareholder of an open-end fund has a taxable gain or loss equal to the difference between the redemption amount and her basis in the stock. ${ }^{217}$

The allocation of the exempt capital gain dividends and the determination of basis are clearly necessary elements of determining a selling or redeeming shareholder's taxable gain. But even with those two issues decided, the sale or redemption raises additional issues that must be resolved. Because, unless a mutual fund shareholder sells or redeems all of her shares in a mutual fund, she must determine which shares she sells. ${ }^{218}$

\footnotetext{
${ }^{212}$ ICI FACTBOOK, supra note 4, at 54. As a result, shareholders in closed-end funds do not face forced realization income; because the fund does not redeem shareholders, it does not need to sell assets to fund redemptions. Still, the tax law treats open-end and closed-end funds the same way, and there is no compelling reason to change that for purposes of the dividend exclusion.

${ }^{213}$ I.R.C. $\$ 1001$ (a) (2006).

${ }^{214}$ Illig, supra note 63, at 294 ("Open-end mutual funds [are] the most popular and common of mutual funds ...."). At the end of 2010, open-end mutual funds had approximately $\$ 11.8$ trillion under management, ICI FАСТВOOK, supra note 4, at 128, while closed-end funds had net assets of about \$241 billion. Id. at 138 .

${ }^{215}$ See Marcel Kahan \& Edward B. Rock, Hedge Funds in Corporate Governance and Corporate Control, 155 U. PA. L. REV. 1021, 1049-50 (2007) (“Open-end mutual funds, by definition and by statute, must also stand ready to redeem their shares at the request of any shareholder at short notice. The redemption price of these shares is based on the fund's net asset value.").

${ }^{216}$ I.R.C. $\$ 302$ (a) (2006).

${ }^{217}$ I.R.C. $\$ 1001(\mathrm{a})$.

${ }^{218}$ The importance of determining which shares she sells is most acute where a shareholder does not use the average basis method. In that case, some of her shares will have a higher basis than others. If she sells less than all of her shares, the amount of taxable gain she recognizes will depend on which shares she sells. If she sells high-basis shares, she will realize less gain than she would if she sold her lowbasis shares. For example, imagine Miles wants to redeem one share of X Mutual Fund, which has a current net asset value of $\$ 75$. He owns three identical shares, one
} 
Determining which shares she sells has a profound impact on her economic well-being. The tax law should not permit shareholders to elect which shares she sells or redeems. True, such an election would not distort a taxpayer's choices. As long as all three shares are identical, a shareholder has no non-tax reason to prefer to redeem share one or share three. But because there is no economic or business consequence to the choice, such an election would always cost the government revenue. The shareholder would always elect to sell or redeem her highest-basis shares first, deferring gain and depriving the government of revenue. ${ }^{219}$

In general, when a taxpayer holds fungible property (such as common stock in the same mutual fund) with differing bases or holding period and she sells less than all of the property, the tax law uses one of two accounting methods to identify which property a taxpayer sells. First-in, first-out ("FIFO") accounting treats a taxpayer as if she sells identical property in the same order she acquired it. ${ }^{220}$ Last-in, first-out ("LIFO") accounting, on the other hand, reverses the

with a basis of $\$ 0$, one with a basis of $\$ 25$, and one with a basis of $\$ 50$. In a world without tax, he does not care which share he redeems; he will have $\$ 75$ cash after his redemption.

In a world that taxes gains, however, that indifference evaporates. Imagine that Miles will pay taxes on his realized gains at a 15 percent rate. If he sells the zero-basis share, he will have $\$ 75$ of taxable income, will owe taxes of $\$ 11.25$, and will be left with $\$ 63.75$ after taxes. If he sells his shares with a basis of $\$ 25$, he will have $\$ 50$ of taxable income, will owe $\$ 7.50$ in taxes, and will have $\$ 67.50$ after taxes. If he sells his share with a $\$ 50$ basis, he will only have $\$ 25$ of taxable income, on which he will owe $\$ 3.75$ in taxes. After taxes, he will keep \$71.25.

${ }^{219}$ Note that if Miles used the average basis method, he would have less ability to reduce his tax liability by choosing to redeem high-basis shares. Even with the average basis method, though, he could have a different basis in shares he purchased and shares he received through a dividend reinvestment plan. To the extent those bases differed, he would always elect to redeem or sell his high-basis shares, of course, because selling the high-basis shares minimizes gain, if any, and maximizes losses, if any.

${ }^{220}$ Edward A. Morse, Demystifying LIFO: Towards Simplification of InflationAdjusted Inventory Valuation, 2 FLA. TAX REV. 559, 563 (1995) ("the first goods purchased or produced during the year are deemed to be the first goods sold, and the ending inventory is composed of the last goods purchased or produced during the current taxable year."). 
order, treating a taxpayer as if she sold the most recent property she acquired first. $^{221}$

Under current law, mutual fund shareholders must generally determine their bases and holding periods using FIFO accounting. ${ }^{222}$ There is no reason to change that rule for purposes of the 10-percent exemption. FIFO accounting would prevent taxpayers from electively reducing government revenue while, at the same time, would treat taxpayers favorably on their gain. ${ }^{223}$

\section{Phaseout}

In addition to the technical aspects of the exemption-its 10 percent limit, its application of the average basis method, and its use of FIFO accounting - the exemption needs to phase out for taxpayers above a certain income level. Phaseouts reduce a tax benefit as a taxpayer's income increases. ${ }^{224}$ The tax law currently contains nearly

${ }^{221} I d$. ("LIFO reverses the FIFO assumption. Inventory on hand at the close of the taxable year is comprised first of those items on hand in the beginning inventory and then, to the extent of any excess, items acquired during the taxable year.").

222 Treas. Reg. $\$ 1.1012-1(\mathrm{c})(1)$ (as amended in 2010).

${ }^{223}$ The average basis method proposed in this Article would appear to limit the ability of mutual fund shareholders to electively reduce their tax bill. Using the average basis method, all of the shares she received pursuant to her dividend reinvestment plan would have an identical basis, and therefore, her tax liability would be the same irrespective of which share she sold. Still, the average basis method does not equalize the basis of all of a mutual fund shareholders shares; it applies only to those shares she receives pursuant to a dividend reinvestment plan, not to shares she purchase on the open market. See supra note 203 and accompanying text. Her basis in purchased shares could, therefore, differ from her average basis in her other shares. Because her shares are all fungible, though, she faces no non-tax economic consequence to determining which shares she sells. If she could elect which shares she sold, she would, therefore, elect to sell the higher-basis shares. Without any non-tax friction preventing her from this type of tax planning, the tax law should prevent this planning opportunity.

At the same time, if the tax law treats a mutual fund shareholder as selling the oldest shares she holds first, it is easier for her to establish a holding period of more than one year in at least some of her redeemed shares. This holding period provides that, upon redemption, she will realize long-term capital gain, taxed at preferential rates. I.R.C. $\S \S 1(h)(1)(c), 1222(3)$ (2006). If, on the other hand, it treats her as selling her most recently-acquired stock first, to avoid being taxed at ordinary rates, she would have to wait until more than one year after she received her last reinvested dividend to sell. Otherwise, every time she received a dividend pursuant to her dividend reinvestment plan, she would reset the clock on at least a portion of her distribution.

${ }^{224}$ Charles S. Hartman, Missed It By That Much: Phase-out Provisions in the Internal Revenue Code, 22 DAYTON L. REV. 187, 188 (1996). 
twenty phaseout provisions which affect as many as one quarter of all taxpayers. $^{225}$

In general, lawmakers should use phaseouts cautiously. Phaseouts increase the tax law's complexity, increasing the administrative burden taxpayers face in complying with their tax obligations. ${ }^{226}$ Moreover, because they make it difficult for a taxpayer to know her tax liability for the year in advance, phaseouts make tax planning and compliance more difficult. ${ }^{227}$

Notwithstanding these problems, though, phaseouts can provide certain benefits. They increase a provision's vertical equity. ${ }^{228}$ The purpose behind the exemption of capital gain dividends is to eliminate the tax disadvantages of mutual fund investments, largely owned by low- and middle-income taxpayers, as compared with direct portfolio investments and investments in private investment funds, almost entirely owned by high-income taxpayers. With no phaseout in the exemption, though, high-income taxpayers could benefit both from the improved tax position of mutual funds and direct investments in securities and private investment funds. Wealthy investors would still have a tax advantage over lower-income investors.

In addition, phaseouts "reduce the revenue loss from a tax benefit because the benefit is limited to lower-income taxpayers, thus increasing the efficiency of the federal income tax."229 Although this exemption has a relatively low tax cost, introducing a phaseout will further reduce the cost of its enactment. ${ }^{230}$ The lower cost may make the provision more politically palatable.

The implementation of phaseout provisions generally falls into one of two categories: they can reduce tax benefits by a constant rate over a specified income range or they can reduce benefits by a

\footnotetext{
${ }^{225}$ Samuel A. Donaldson, The Easy Case Against Tax Simplification, 22 VA. TAX REV. 645, 722-23 (2003).

${ }^{226} 2$ JoInt COMmitTeE On TAX’N, 107Th CONG., Study OF THE OVERALl STATE OF THE FEDERAL TAX SYSTEM AND RECOMMENDATIONS FOR SIMPLIFICATION, PURSUANT TO SECTION 8022(3)(B) OF THE INTERNAL REVENUE CODE OF 1986, at 87 (Joint Comm. Print 2001).

${ }^{227} I d$. at 88 .

${ }^{228}$ Donaldson, supra note 225, at 724 ("Policymakers design phaseouts to enhance vertical equity.").

${ }^{229}$ Id. at 725.

${ }^{230}$ See supra note 141 and accompanying text.
} 
specified amount for each additional increment of income. ${ }^{231}$ The credit for adoption expenses, for example, phases out at a constant rate-under the Code, for every $\$ 100$ of adjusted gross income in excess of $\$ 150,000$, a taxpayer must reduce her credit by 0.25 percent. ${ }^{232}$ The credit phases out entirely at $\$ 190,000$ of adjusted gross income. $^{233}$ The deduction for qualified tuition, on the other hand, is reduced by a specified amount for each additional increment of income. For years beginning after 2003, a single taxpayer can deduct $\$ 4,000$ if her adjusted gross income does not exceed $\$ 65,000 .{ }^{234}$ The available deduction drops to $\$ 2,000$ if her adjusted gross income is more than $\$ 65,000$ but not more than $\$ 80,000$, and drops to $\$ 0$ if her adjusted gross income exceeds $\$ 80,000$. $^{235}$

It does not matter, in this second type of phaseout, if the taxpayer's adjusted gross income exceeds $\$ 65,000$ by $\$ 1$ or by \$25,000: either way, she loses half of her tax benefit. For these purposes, phasing out the benefit at a constant rate appears preferable. Because the exclusion phases out at a constant rate, taxpayers do not face a cliff effect, where one additional dollar of income causes their taxes to increase by more than one dollar. Thus, a constant-rate phaseout introduces fewer distortions into a taxpayer's calculation about whether to earn an additional dollar of income.

The next step after determining that the phasout of the capital gain dividend exemption should use a constant-rate phaseout, is to determine the threshold amounts for where the phaseout begins and ends. The purpose of the exemption is to reduce the tax disadvantages of mutual funds so that low- and middle-income households do not face higher rates of tax on their investments than wealthy individuals. As such, the phaseout needs to be high enough that it does not affect these households. At the same time, it should be low enough that wealthy households cannot benefit from additional tax advantages.

\footnotetext{
${ }^{231}$ Roberton Williams, How Do Phaseouts of Tax Provisions Affect Taxpayers?, in The TAX Policy BRIEFING BoOK: A CiTIZENS' GuIDE FOR THE 2012 ELECTION AND BEYOND, at I-7-6 (2011) (available at http://www.taxpolicycenter.org/upload/Background/I-7IncomeTaxIssues.final.pdf) (on file with author).

${ }^{232}$ I.R.C. $\S 36 \mathrm{C}(\mathrm{b})(2)(\mathrm{A})$.

${ }^{233} \mathrm{Id}$. The credit is indexed for inflation so, in practice, these numbers will be slightly different, but the concept is the same. Id. \$36C(h).

${ }^{234}$ Id. $\$ 222(\mathrm{~b})(2)(\mathrm{B})(\mathrm{i})$.

${ }^{235}$ Id. $§ 222(\mathrm{~b})(2)(\mathrm{B})(\mathrm{ii})$, (iii).
} 
No clear line separates a middle-class income from a high income. ${ }^{236}$ Still, data about relative incomes can help design a fair line for the phaseout to begin and end. According to the I.R.S.'s data, in 2008 , the top 10 percent of tax returns showed an adjusted gross income of at least $\$ 113,799$, the top 5 percent showed an adjusted gross income of at least $\$ 159,619$, and the top 1 percent showed an adjusted gross income of at least $\$ 380,354 .{ }^{237}$ While any of these numbers could provide a starting point for the phaseout, I recommend that for joint filers the exemption begin to phase out at $\$ 170,000$ and that it phase out completely at $\$ 220,000 .{ }^{238}$ Moreover, the phaseout should be indexed to inflation so that it does not start creeping down and disallowing the exemption for middle-class shareholders.

With the phaseout set at these levels, more than 95 percent of taxpayers can enjoy the full exemption, while the exemption will not be available to those whose income puts them above the top 5 percent of income earners, inarguably one legitimate dividing line between the middle-class and the wealthy. Doing so will increase the vertical equity of the exemption, improving the tax situation of low- and middle-income taxpayers while requiring those who can pay more taxes to do so.

In addition to the phaseout's roughly corresponding to the line between the top five percent of income-earners and the bottom 95 percent, starting to phase the exemption out at $\$ 170,000$ tracks two

${ }^{236}$ See, e.g., Catherine Rampell, Who Counts As 'Rich'?, Economix, http://economix.blogs.nytimes.com/2011/12/09/who-counts-as-rich/ (Dec. 9, 2011, 14:40 EST) (discussing various views of what it means to be rich).

${ }^{237}$ Kyle Mudry, Individual Income Tax Rates and Shares, 2008, STANDARDS OF INCOME BULLETIN 22, 63 (Winter 2011). The Tax Policy Center has done a finergrained calculation of income percentages. According to its numbers, in 2011, a married couple filing jointly needed to have "cash income" of at least $\$ 298,736$ to make it into the 95th percentile, while for unmarried taxpayers needed $\$ 87,149$, and the 95th percentile for all tax units began at $\$ 200,000$. Income Breaks, 2011, http://taxpolicycenter.org/numbers/displayatab.cfm?DocID=2970 (last visited Jun. 7, 2012). The Tax Policy Center's "cash income" differs significantly from adjusted gross income, though, by adding back deductions and adding in nontaxable income, including tax-exempt interest and payroll taxes paid by a taxpayer's employer. Income Breaks for Distribution Tables, 2004-2022, http://www.taxpolicycenter.org/numbers/displayatab.cfm?DocID=574 (last visited Jun. 7, 2012). As such, even though its data is more specific, the Tax Policy Center's numbers are less helpful in determining an appropriate phaseout.

${ }^{238}$ For single individuals, the phaseout should begin at about $\$ 100,000$ of income. $C f$. infra notes 239-240 (Roth IRA limitation begins at $\$ 110,000$, while itemized deduction phaseout began at $\$ 83,400$ for single taxpayers). 
other phaseout provisions intended to provide benefits to the low- and medium-income taxpayers, but not to high-income taxpayers. Joint filers' ability to put money into a Roth IRA phases out between $\$ 173,000$ and $\$ 183,000$ in $2012 .{ }^{239}$ And in 2009, a joint filer's ability to use itemized deductions began to phase out when she reached $\$ 166,800$ of income. ${ }^{240}$ Both phaseouts apply to high-income taxpayers, and both start at income levels close to that proposed in this Article. This provides additional support for beginning the phaseout at $\$ 170,000$.

\section{E. Illustrating the Exemption}

The combination of assigning basis using the average basis method and requiring shareholders to use FIFO accounting upon the redemption of shares benefits both the government (by preventing tax planning) and the shareholder (by permitting her to maximize the amount of her income that consists of long-term capital gain). The benefits of the rules proposed in this Article can be illustrated with an example.

Mary files a joint return with her husband; in 2012 and 2013, they had a combined taxable income of $\$ 75,000 .^{241}$ Assume that Mary purchased 10 shares of Y Mutual Fund on January 1, 2012, for $\$ 100$ per share. On December 1, 2012, the fund paid Mary a $\$ 180$ dividend, of which it designated $\$ 80$ as capital gain dividends. Pursuant to Mary's dividend reinvestment plan, she received the dividend in the form of an additional three shares of Y Mutual Fund. On February 1, 2013, Y mutual fund paid an additional \$220 dividend, \$120 of which it designated as capital gain dividends, and which Mary received in the form of an additional two shares of Y Mutual Fund. On February 28, 2013, Y Mutual Fund redeemed 11 of Mary's shares for $\$ 110$ per share.

\footnotetext{
${ }^{239}$ I.R. 2011-103 (Oct. 20, 2011).

${ }^{240}$ Rev. Proc. 2008-66, 2008-2 C.B. 1107. Under the Bush tax cuts, the phaseout of itemized deductions was eliminated for taxable years beginning after December 31, 2009. I.R.C. $§ 68(\mathrm{~g})$; see also Rev. Proc. 2009-50, 2009-2 C.B. 617. Though it will be reinstated for taxable years beginning after December 31, 2012, see Economic Growth and Tax Relief Reconciliation Act of 2001, P.L. 107-16, §901(a), as amended by P.L. 111-312, § 101(a)(1), the I.R.S. does not provide the inflationadjusted amount that would otherwise apply for years after 2009.

${ }^{241}$ With joint income of $\$ 75,000$, the phaseout would not apply. In 2012, Mary and her husband would pay taxes at a marginal rate of 25 percent. Rev. Proc. 2011-45 $\S$ 3.01, 2011-45 I.R.B. 701.
} 
Under the capital gain dividend exemption, assuming that her income did not exceed the phaseout threshold, Mary could exempt $\$ 8$ of the December 1 dividend and $\$ 12$ of the February 1 dividend from her income. As a result, she would pay taxes on $\$ 172$ of her mutual fund dividends in 2012 and on \$208 in 2013.

Under the average basis method, Mary would have two blocks of stock. She would have a basis of $\$ 100$ per share in the shares she purchased. Her basis in shares acquired pursuant to her dividend reinvestment plan would initially be $\$ 60$ per share. ${ }^{242}$ But as of February 1, 2013, her basis in her unpurchased shares changes: now, she has a basis of $\$ 80$ in each of the five shares she received pursuant to the dividend reinvestment plan. ${ }^{243}$

Because she determines which shares she redeemed using FIFO accounting, the tax law treats Mary as if she redeemed the ten shares she purchased, as well as one share she received as a dividend. Because she has held her purchase shares for longer than a year, her $\$ 100$ of gain on her purchased shares qualifies as long-term capital gain, taxable at a 15 percent rate. Her $\$ 30$ gain on the share she received as a dividend, however, will not qualify as long-term capital gain, and she will pay taxes on that gain at her ordinary rate. As a result, Mary owes $\$ 22.50$ in taxes on the proceeds of her redemption. $^{244}$

\section{CONCLUSION}

This Article joins a surprisingly small chorus calling for the reform of mutual fund tax rules. Rather than explore the whole world of those rules, though, it focuses on a single inequity found in the rules: the taxation of mutual fund shareholders on forced realization income.

Forced realization income exists as a result of the combination of mutual funds' obligation to redeem shareholders on demand and the requirement that they distribute substantially all of their capital gains. These two requirements, separately, cause mutual funds to approximate direct investments. But as a result of their interaction, mutual fund investors face additional tax costs that rich investors can

\footnotetext{
${ }^{242}$ A $\$ 180$ dividend divided among the three shares Mary received gives her a basis of $\$ 60$ per share.

${ }^{243}$ That is, she has basis of $\$ 180$ from the first set of reinvested shares plus $\$ 220$ from the second set. Mary must then divide that $\$ 400$ of basis between the five shares she received pursuant to her reinvestment plan.

${ }^{244}(\$ 100 \times 15 \%)+(\$ 30 \times 25 \%)=\$ 22.50$.
} 
avoid. These costs may be the inevitable result of designing a quasipass-through entity like a mutual fund, but no tax policy justifies the additional expense. In fact, vertical equity considerations argue against mutual fund investors facing a higher tax burden than wealthier investors who can afford to assemble a diversified portfolio or invest in hedge funds or private equity funds.

Moreover, although the additional tax costs may be inevitable, they can be ameliorated within the basic framework of the existing rules. This Article proposes a specific reform-the exemption of up to 10 percent of the capital gain dividends from mutual fund shareholders' income-that would largely ameliorate the problem of forced realization income. And even unsophisticated taxpayers could understand and comply with the requirements.

This administrability admittedly comes at the cost of precision; for some investors, the exemption will exceed the actual forced realization income they receive from their mutual funds, while, for some, it may understate their forced realization income. Nonetheless, even where it understates the forced realization income, the exemption at least reduces the tax consequences to shareholders. And it is an affordable reform.

Mutual funds are such an important investment vehicle that other aspects of their taxation merit further consideration. But providing this exemption would be a significant step in the direction of making available to poor and middle-class Americans a fair and equitable vehicle for investment and reducing the difference between the rich and the rest of us. 